\title{
O papel do BNDES e o financiamento do desenvolvimento: considerações sobre a antecipação dos empréstimos do Tesouro Nacional e a criação da TLP *
}

\author{
Thiago Rabelo Pereira ** \\ Marcelo Trindade Miterhof ${ }^{* * *}$
}

\begin{abstract}
Resumo
O artigo discute a decisão do governo Temer de devolver antecipadamente, de dezembro de 2016 a agosto de 2018, $\mathrm{R} \$ 280$ bilhões de empréstimos do Tesouro ao BNDES e de indexar o custo do crédito ofertado à curva de títulos públicos de 5 anos em IPCA, pela criação da TLP em substituição à TJLP. Para além dos aspectos legais, são avaliadas as implicações econômicas e alocativas de tais medidas. Defende-se que a visão tradicional, que circunscreve a missão de um banco de desenvolvimento (BD) à correção do desvio entre os retornos social e privado de projetos intensivos em externalidades, deve ser combinada a uma atuação de caráter estabilizador, via canal do crédito, de um BD atuando em escala sistemicamente relevante em contraponto as propensões pró-cíclicas e de curto prazo da finança privada. Em particular, deve-se considerar a contribuição do BNDES como mitigador da severidade extrema do racionamento de crédito de longo prazo no Brasil, associada aos juros historicamente altos, o que inibe o investimento privado e gera viés contra projetos capital intensivos e portadores de ganhos de escala relevantes. Assim, é preciso avaliar os custos, mas também os benefícios fiscais derivados de sua contribuição ao crescimento econômico e à estabilidade financeira. Também são propostas mudanças na regra de formação do custo do crédito, via TLP, visando preservar alguma flexibilidade para os formuladores de política responderem aos desafios presentes em cada conjuntura econômica.
\end{abstract}

Palavras-chave: BNDES; Banco de desenvolvimento; Estabilidade financeira; Financiamento de longo prazo; Institucionalidade financeira; TJLP; TLP.

\section{Abstract \\ The role of BNDES and financing development in Brazil: an analysis of treasury loan prepayments and the creation of TLP}

The article discusses the decision of the Brazilian government to prepay $\mathrm{R} \$ 280$ billion in Treasury loans to the BNDES and also to index the cost of BNDES funding to a 5-year market rate indexed to IPCA, through the substitution of TJLP for the new TLP. In addition to the legal aspects, the allocative and economic implications are assessed. It is argued that the traditional view, which circumscribes the mission of a development bank to the correction of deviations between the social and private return of projects intensive in externalities, should be combined with a vision emphasizing the stabilizing character, via the credit channel, of a development bank, acting in a relevant systemic scale, as a tool to offset the pro-cyclical and short term propensities of private finance. Furthermore, we should consider its contribution to development through the mitigation of the extreme severity of long-term credit rationing over private investment in Brazil linked to the historically high interest rates, that removes

\footnotetext{
* Artigo recebido em 8 de setembro de 2016 e aprovado em 12 de janeiro de 2018. O artigo não reflete necessariamente a opinião do BNDES.

${ }^{* *}$ Economista do Banco Nacional de Desenvolvimento Econômico e Social (BNDES), Brasília, DF, Brasil. E-mail: thiago.rabelo.pereira@gmail.com.

${ }^{* * *}$ Economista do Banco Nacional de Desenvolvimento Econômico e Social (BNDES), Brasília, DF, Brasil. E-mail: marcelo.miterhof@gmail.com.br.
} 
a bias against capital intensive projects and those with significant potential scale economies. The paper emphasizes the need for an evaluation of both the costs and the fiscal benefits derived from the banks' contribution to economic growth and financial stability. It also proposes a change in the rule of formation of the new TLP such as to preserve some degree of flexibility required for policy makers to be able to react to the challenges posed to monetary and credit policies in different economic contexts.

Keywords: BNDES; Development Bank; Credit rationing; Financial stability; Long term financing; TJLP; TLP. JEL G2.

O BNDES nos últimos anos vem sendo alvo de inúmeros e crescentes questionamentos, o que reflete a ampliação de seus desembolsos de 2008 a 2010, com sua manutenção até 2014 num patamar menor, mas ainda elevado.

Gráfico 1

Desembolsos do BNDES 2007-2016

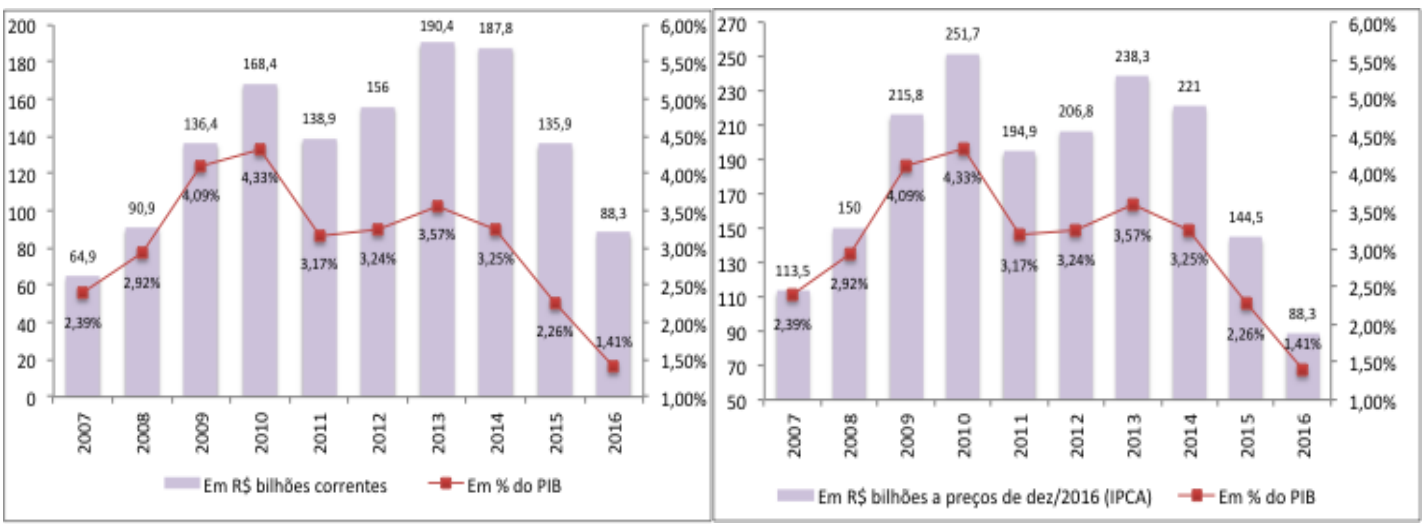

Fonte: BNDES.

O BNDES foi um relevante instrumento do esforço contracíclico empreendido pelo governo federal no segundo mandato do presidente Lula para enfrentar os efeitos deletérios da crise financeira internacional iniciada em 2007/8 ${ }^{1}$. Para tanto o BNDES recebeu empréstimos de longo prazo (cerca de quatro décadas) do Tesouro Nacional (TN) para ampliar suas fontes de recursos, tendo por base o custo financeiro da Taxa de Juros de Longo Prazo (TJLP).

De 2008 a 2014, foram cerca de R \$ 420 bilhões recebidos pelo Banco. Não há dúvida quanto à aplicação desses recursos. O BNDES tem como função precípua financiar o investimento produtivo, apoiando obras civis, a aquisição de equipamentos e o desenvolvimento de capacitações empresariais e laborais.

(1) Sobre esse ponto vale conferir o depoimento do então presidente do BNDES, Luciano Coutinho, retratado pelo professor da Unicamp Fernando Nogueira da Costa: https://fernandonogueiradacosta.wordpress.com/2011/11/28/atuacao-anticiclica-do-bndes/. 
A necessidade de recursos adicionais decorreu da aceleração do investimento. De 2000 a 2007, a taxa de investimento média da economia brasileira foi, segundo dados do IBGE, de 17\% do PIB. De 2008 a 2014, esse indicador saltou para $20 \%$.

Esse sucesso atraiu a atenção internacional para o BNDES. Porém também trouxe críticas. Essa disputa reproduz uma velha clivagem ideológica, presente na sociedade e entre economistas, quanto ao papel do Estado no desenvolvimento. Em especial no Brasil, essas críticas se avolumaram à medida em que se agravaram os conflitos distributivos e políticos no país.

Os focos de questionamento envolvem questões fiscais (o impacto na dívida bruta e o "subsídio" ou custo fiscal implícito associado à diferença entre a Selic e a TJLP); de política monetária (a TJLP provocaria uma perda de sua potência e seria um dos fatores responsáveis pelos juros altos); de escolhas dos investimentos apoiados (os ditos "campões nacionais", o financiamento às exportações brasileiras de bens e serviços de engenharia etc.); e até de ordem criminal.

Após a deposição da presidente eleita Dilma Rousseff, em meados de 2016, o governo federal tomou duas inciativas que podem mudar drasticamente o perfil da atuação do BNDES. A primeira foi antecipar o pagamento de $\mathrm{R} \$ 100$ bilhões, ocorrido em dezembro de 2016, dos empréstimos do TN ao Banco em TJLP2.

A medida foi justificada por tais recursos estarem supostamente ociosos no banco, no cenário de recessão, além de supostamente gerar economia financeira anual estimada em cerca de R 7 bilhões, via redução do custo de carregamento dos créditos ao BNDES, remunerados a TJLP e financiados pelo custo da dívida pública. Na época, a diferença entre a TJLP e a Selic era da ordem de 7 pontos percentuais, o que aplicados sobre os $\mathrm{R} \$ 100$ bilhões geraria a suposta economia fiscal.

A segunda foi a edição da Medida Provisória n. 777, de 26/04/2017³, que mudou, a partir de janeiro de 2018, o custo financeiro básico do BNDES para uma nova taxa, chamada TLP (taxa de longo prazo), que na prática deverá fazer o custo do funding institucional do BNDES para apoio a novos projetos convergir linearmente num prazo de cinco anos para a taxa negociada em mercado secundário de um título público indexado ao IPCA, de prazo de cinco anos, a NTN-B, eliminado o custo fiscal implícito decorrente da diferença de remuneração entre os recursos emprestados ao BNDES e o custo do serviço da dívida pública.

Ao mesmo tempo em que se eliminam os "subsídios" implícitos aos novos financiamentos, esses passarão a ser efetuados em taxas fixas de juros, formadas com base no

(2) Entre a submissão do artigo e a preparação do texto para a publicação, mais R $\$ 180$ bilhões foram adiantados pelo BNDES ao Tesouro Nacional, totalizando uma antecipação de R $\$ 280$ bilhões de dezembro de 2016 a agosto de 2018. Como essa ampliação não muda os argumentos, as referências às antecipações foram, salvo indicação em contrário, mantidas em R\$100 bilhões. Da mesma forma, outras atualizações foram feitas quando necessárias, mas preservando os dados antes disponíveis, de maneira a evitar a criação de inconsistências nos argumentos.

(3) Posteriormente, a MP n. 777 foi convertida na Lei 13.483/2017, de 21/09/2017. 
retorno das NTN-Bs vigente quando da contratação dos créditos, acrescido dos spreads aplicáveis. Essa taxa fixa será mantida ao longo da vida dos empréstimos, incidindo sobre o principal indexado ao IPCA.

A regra anterior - uma taxa flutuante e administrada, vigente ao longo da vida dos projetos, definida pelo Conselho Monetário Nacional $(\mathrm{CMN})$ em patamar em geral inferior às taxas de mercado (a Taxa de Juros de Longo Prazo - TJLP) - seria mantida apenas para os contratos vigentes antes da implementação da nova regra.

Essas medidas fazem parte de um conjunto bem mais amplo de mudanças que visam restringir o gasto público e os graus de liberdade da política fiscal, que também envolve a PEC do Teto dos Gastos e a reforma da Previdência.

A aposta é de que as medidas recuperem a confiança de empresários, investidores e consumidores ao sinalizar a solvência intertemporal do setor público, em função da reforma da institucionalidade fiscal, com limitação no espaço para ampliação dos gastos primários - isto é, não financeiros - do setor público ${ }^{4}$.

A ideia da austeridade expansionista está ancorada na crença de que a suposta mudança na percepção de sustentabilidade das contas públicas gerará retomada da confiança e redução no prêmio de risco implícito no preço dos ativos e no custo de capital das empresas, com efeito líquido positivo sobre os investimentos e consumo privado em intensidade suficiente para mais do que compensar o impacto diretamente contracionista do ajuste fiscal - que gera destruição de demanda efetiva via corte de gastos públicos e elevação de tributos.

A pertinência dessas medidas - anunciadas como parte da agenda supostamente saneadora e de restauração do compromisso com a "responsabilidade fiscal" - precisa ser mais bem discutida.

Para isso, o artigo será dividido em duas seções, além desta introdução e das considerações finais. A primeira trata do papel da TJLP e da proposta de sua substituição pela TLP. A segunda trata dos empréstimos do TN ao BNDES e das devoluções antecipadas ocorridas desde dezembro de 2016.

\section{TJLP versus TLP}

Em abril de 2017, o governo federal lançou a MP 777 que pretende progressivamente substituir a atual TJLP, atualmente definida pelo Conselho Monetário Nacional, (CMN) por taxa igual à NTN-B de cinco anos, um título indexado ao IPCA ao qual se soma uma parcela

(4) Cabe salientar que eventuais custos para o erário, decorrentes dos subsídios implícitos na modulação das políticas creditícias do governo, representam despesa nominal, e não primária, estando fora do alcance da PEC do Teto dos Gastos, assim como os custos implícitos com carregamento de reservas cambiais (responsável por cerca de 2/3 da diferença entre o custo médio do serviço da dívida liquida em relação ao custo da dívida bruta) ou os efeitos diretos da Selic sobre o gasto nominal com juros, decorrentes das decisões de política monetária. 
de taxa de juros fixa, que em dezembro de 2016 estava em cerca de $6 \%$ a.a., em julho de 2017 estava em $4,7 \%$ a.a. e em setembro de 2018 era de $5,5 \%$ a.a. $^{5}$

A lógica seria reduzir o custo fiscal direto da atuação do BNDES e tornar o custo de seus financiamentos mais previsível, além de passível de gerenciamento financeiro via derivativos, pois a taxa passa a ser referenciada ao mercado e fixada para toda a vida da operação. Pressupõe-se que, numa perspectiva de convergência da Selic ao padrão global de juros, o BNDES poderia captar recursos mais intensivamente nos mercados, além de permitir a securitização dos créditos concedidos ${ }^{6}$.

Ignora-se se foram avaliados os custos fiscais indiretos, já que a pressão sobre o custo de capital oferecido pelo BNDES desestimula o investimento e o crescimento, reduzindo a arrecadação tributária.

A medida parece se apoiar na tese de que o crédito direcionado limitaria a atuação do restante do mercado financeiro, causando a persistência do juro alto no Brasil, resultado de menor concorrência e/ou de uma reduzida efetividade da política monetária.

\subsection{A singularidade do BNDES}

De início, vale caracterizar em que medida o BNDES é uma instituição singular.

Bancos de desenvolvimento (BDs) existem em vários países, incluindo de renda alta, como Alemanha, Coreia do Sul e Japão. Desde a última crise financeira internacional, iniciada em 2007/8, os BDs voltaram à discussão global como instrumento de atuação contracíclica e complementar ao mercado de capitais e ao sistema de crédito comercial.

O diagnóstico é que as finanças privadas frequentemente não conseguem atuar com o perfil de risco e o horizonte de longo prazo requeridos por algumas atividades cruciais ao desenvolvimento, bem como não oferecem solução alocativamente eficiente para a

(5) Fonte: Anbima.

(6) A justificativa da MP 777 com base no argumento oficial de que esta propiciaria maior facilidade para a securitização da carteira de crédito do BNDES deve ser vista com cautela. Primeiro, porque os instrumentos financeiros são meios para a obtenção de fins e não fins em si mesmos. Sob a ótica do custo de captação em fontes do mercado local, as estruturas de securitização, que são mais complexas, envolvem no caso brasileiro elevado prêmio exigido pelos investidores relativamente a alternativas de renda fixa convencionais de classificação de risco equivalente. Ou seja, a securitização tende a ser mais cara do que alternativa de captação a custos de mercado via emissão de letras financeiras ou debêntures, por exemplo. Ela passa a ser atrativa financeiramente apenas no caso de abrir acesso a crédito que esteja racionado ou gerar captação mais barata, quando o emissor tem pior classificação de risco do que o do conjunto dos recebíveis a serem cedidos ao mercado. Ou ainda caso faculte a redução substantiva de risco de crédito ou de descasamento de taxa de juros em balanço, permitindo, no caso dos bancos, a apropriação de eventual economia de capital regulatório, com a redução dos ativos ponderados pelo risco, decorrentes da venda da carteira. Entretanto, a regulação bancária, desde a última crise financeira internacional, tem vedado a baixa contábil integral dos ativos e impedido a apropriação de ganhos de capital regulatório, salvo se ocorrer a transferência integral dos riscos da carteira cedida para o mercado, o que inviabilizaria estruturas com retenção de uma cota subordinada pelo BNDES. Isso torna a venda em larga escala virtualmente impossível no mercado local. Na prática a securitização possível será mais cara do que as alternativas de captação convencionais nos mercados disponíveis para o BNDES - sendo tal argumento usado como uma espécie de cortina de fumaça para justificar outros objetivos associados a limitação do escopo e escala de atuação do BNDES. 
intermediação financeira na presença de atividades intensivas em externalidades, mesmo no caso de mercados profundos e maduros. Exemplo eloquente é o dos EUA, que não tem um BD nacional e, embora tenha o mais profundo mercado de capitais do mundo, apresenta infraestrutura deficiente para o padrão dos países de alta renda ${ }^{7}$.

Portanto, o BNDES não é uma instituição anômola. Ainda assim, o que ele tem de distintivo? Como mostra o gráfico a seguir, o Banco tem uma carteira de ativos compatível com as dos principais BDs nacionais do mundo se a comparação é feita com o PIB de cada país, sendo menor que o alemão KfW e o chinês CDB.

Gráfico 2

Participação BDs selecionados PIB e Estoque de Crédito do País (\%) - 2014

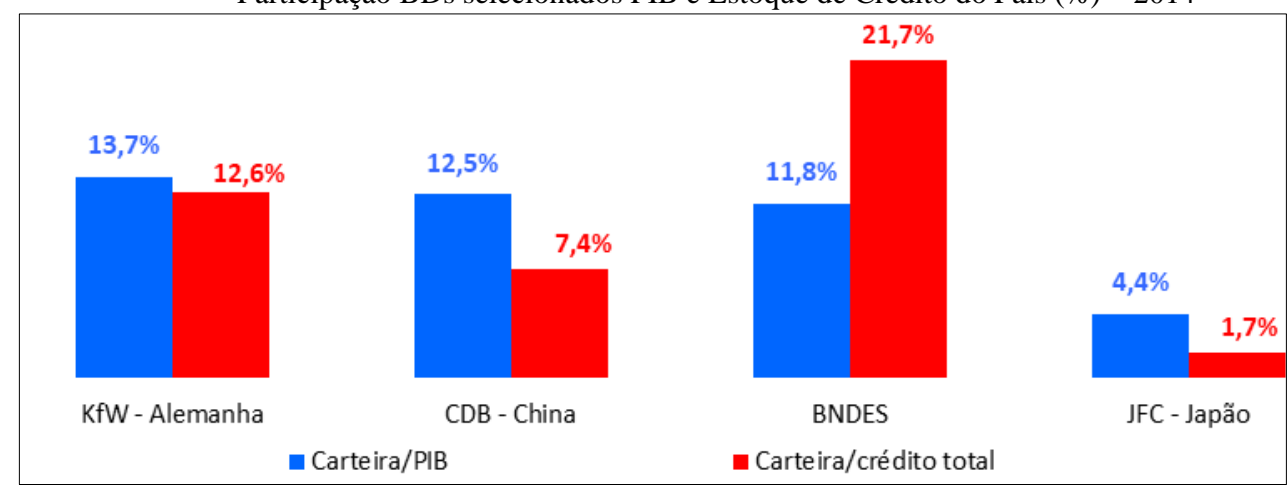

Fonte: Demonstrações financeiras, FMI e Banco Mundial/Elaboração: BNDES.

Esse quadro muda se o critério da comparação é o volume total de crédito da economia. O motivo é que a economia brasileira ainda tem um baixo nível de crédito em relação ao PIB, um sintoma das taxas de juro elevadas. Nos demais países, essa relação é de mais de $100 \%$ enquanto no Brasil era de cerca de $50 \%{ }^{8}$.

Esta é a singularidade do BNDES: seu papel de mitigar a severidade atípica da restrição de crédito de longo prazo em moeda local. Assim, a discussão relevante passa a ser por que a economia brasileira sofre há tanto tempo com juros tão altos.

\subsection{As causas das taxas de juros elevadas}

Os defensores da MP 777 entendem que a atuação do BNDES com base numa taxa de captação privilegiada é uma das causas centrais do juro alto na economia brasileira. Isso se expressaria por dois canais: a perda de potência da política monetária, pressionando a taxa Selic pelo canal do crédito, e a existência de uma concorrência "espúria" no sistema bancário,

(7) Siffert Filho e Puga (2016) mostra que os EUA ocupam o terceiro lugar no índice global de competitividade do World Economic Forum 2016-2017, mas apenas a $12^{\mathrm{a}}$ posição do ranking de qualidade da infraestrutura em geral.

(8) Outros países "emergentes" têm estoque de crédito abaixo de $100 \%$ do PIB, mas no Brasil chama a atenção que o crédito de longo prazo seja praticamente nulo se tiradas as fontes institucionais. 
acarretando em seleção adversa que atrairia para o BNDES os tomadores de melhor risco e pressionaria os spreads praticados no segmento livre, que concentraria os piores riscos de crédito 9 .

Quanto à política monetária, o problema seria que, como uma parte da demanda agregada - o investimento financiado pelo BNDES - não é afetada diretamente por variações da Selic, são necessárias taxas de juros mais altas para manter a inflação sob controle, tudo o mais constante.

$\mathrm{O}$ argumento supõe que a inflação é um fenômeno causado principalmente por excesso de demanda, ignorando fontes notórias de pressão de custo, como a história brasileira de problemas de balanço de pagamentos e volatilidade cambial, o sistema de metas de inflação, dependente fortemente da valorização cambial, e as tensões distributivas expressas na dinâmica dos preços.

Enquanto o mundo opera há mais de uma década com juros reais (descontada a inflação) básicos próximos de zero, no Brasil esse nível estava, em julho de 2017, em mais de $6 \%$ a.a. ${ }^{10}$, tendo frequentemente estado no patamar de $10 \%$ a.a. Por um longo período, a TJLP esteve em termos reais próxima de zero. Entretanto, em julho de 2017, estava nominalmente em $7 \%$ a.a., representando uma taxa real anual de $3,7 \%$ a.a.

O argumento é problemático. Uma taxa, a Selic, é alta em relação ao padrão internacional. E a culpada disso seria outra taxa, a TJLP, que é mais compatível com tal padrão. A solução para a Selic cair para a média global seria elevar a TJLP!

(9) Ver, por exemplo Bolle (2015). A tese atribui os elevados spreads bancários praticados no segmento de crédito livre às empresas, aos efeitos de suposta seleção adversa associada aos termos mais atrativos do crédito do BNDES em TJLP. Ela perde força quando se avalia o elevado peso das operações indiretas, realizadas pelo BNDES junto com o sistema de bancos comerciais, bem como desconsidera o argumento clássico sobre as origens da seleção adversa e do racionamento de crédito como sua consequência.

Diante de assimetria de informação entre credores e devedores, taxas de juros elevadas tendem a operar como fator decisivo para piorar a qualidade do conjunto de tomadores, pois as melhores empresas buscam alternativas, como o autofinanciamento, para evitar captações custosas. Além disso, De Bolle desconsidera que, mesmo quando existe apetite dos bancos privados para assumir o risco de crédito de empresas de primeira linha, as fontes de mercado usualmente esbarram na incapacidade de equacionar o funding do crédito de longo prazo em volume e taxas em patamar satisfatório. Aversão ao risco de taxa de juros e baixa demanda por duration demandaram solução institucional via poupança compulsória e mecanismos parafiscais justamente para evitar o racionamento de crédito quase absoluto nos segmentos de longo prazo.

Por fim, a tese da seleção adversa como chave explicativa para os diferenciais dos spreads bancários observados entre os segmentos de crédito livre e direcionado, defendida pela autora, parece não ter aderência aos dados, como mostra o Gráfico 3. Isto porque a margem operacional bruta do BNDES é muito menor do que os spreads que os bancos comerciais cobram das empresas no crédito livre, mesmo quando se desconta a inadimplência observada ex post, o que é uma forma de ajustar o custo do crédito ao perfil de risco dos clientes.

(10) Em 26/7/2017, o BC fixou a Selic nominalmente em 9,25\% a.a., enquanto a variação esperada do IPCA para 2017, segundo o boletim Focus de 21/7/2017, era de 3,3\%. Em 19/9/2018, o BC fixou a Selic em 6,5\% a.a. sendo 4,3\% a variação esperada do IPCA para 2018, segundo o boletim Focus de 21/9/2018. Esse recente patamar de juros reais, mais baixo do que o historicamente observado, está associado à prolongada recessão/estagnação desde 2015. 
Mesmo sob uma hipótese de inflação de demanda, é preciso ter em conta que o crédito em TJLP do BNDES atua sobre o investimento não-residencial. Porém, qual o impacto potencial disso?

É preciso fazer uma distinção entre fluxo e estoque. Em novembro de 2016, o crédito do BNDES respondeu por 19,9\% do estoque de crédito total. Mas representou somente $2,8 \%$ das concessões totais de crédito em 12 meses. Nos cinco anos anteriores, os máximos foram respectivamente de $21,2 \%$ e $5,1 \%$. A comparação com o PIB elimina distorções como a do cartão de crédito, que pode estar sujeito a renovações consecutivas em um mesmo ano. Em novembro de 2016, o estoque de crédito direcionado via BNDES correspondeu a 9,9\% do PIB, ante apenas 1,5\% do PIB de participação das concessões (fluxo). Os recordes nos últimos cinco anos foram de $11,3 \%$ e $3,5 \%$, respectivamente ${ }^{11}$.

Ao que parece, é preciso buscar explicações alternativas para o que podemos chamar de falha macroeconômica estrutural dos juros altos.

O juro alto é causado por uma história de dificuldades de balanço de pagamentos, um sistema de metas de inflação que depende fortemente da valorização cambial para ser cumprido pela indexação residual, que gera inércia inflacionária renitente, e por ativos financeiros atrelados à taxa do CDI (baseada na Selic) em um quadro de percepção de fragilidade fiscalfinanceira do setor público.

Não é a TJLP que faz a Selic ser alta. Ao contrário, foi a persistência de elevadas taxas de juro de mercado que exigiu na década de 1990, durante a implementação do Plano Real, a criação da TJLP como custo financeiro em moeda local - sem risco cambial, do crédito direcionado para projetos de empresas que têm suas receitas predominantemente em reais para preservar o investimento.

Nesse sentido, ainda que antecipando o que será discutido na seção 1.4, vale destacar a funcionalidade que a existência da TJLP trouxe para a execução da política econômica, mitigando os sintomas dos juros altos.

Os mecanismos parafiscais de funding (FAT, PIS-Pasep e, mais recentemente, os empréstimos do Tesouro lastreados na emissão de dívida pública, etc.), conjugados a uma regra de formação da TJLP que reservava espaço discricionário na fixação do custo básico do crédito do BNDES, oferecia às autoridades monetárias a capacidade de proteger o núcleo mais produtivo da formação de capital dos efeitos do patamar - caso esse fosse entendido como excessivo - dos juros básicos requeridos para atrair e manter recursos externos de portfólio em escala que estabilize a inflação via canal do câmbio.

Com conta capital aberta e um regime rígido de metas de inflação, o juro básico em moeda local deve respeitar o piso definido pela soma do diferencial dos riscos de crédito soberano (precificados nos mercados de bônus e de derivativos de crédito off shore), da

(11) A fonte é o Banco Central (BC). Como o BNDES é o principal financiador de longo prazo da economia brasileira, sua maior participação no estoque do que no fluxo de crédito reflete o maior prazo médio ponderado ("duration”) de sua carteira em relação ao restante do sistema financeiro. Agradecemos a Fernando Pimentel Puga, que fez as contas apresentadas. 
depreciação cambial esperada e da remuneração requerida pelos investidores externos para compensar os riscos percebidos de volatilidade cambial e de conversibilidade.

Caso as condições internas e externas gerem elevada percepção de risco nas aplicações em moeda local, impondo alto patamar de juro real doméstico, na ausência de arranjo institucional mitigador desses impactos sobre o custo do crédito ao investimento, a condição financeira de equilíbrio de portfólio externo pode acarretar em desequilíbrio persistente e cumulativo nos mercados de bens e de trabalhos domésticos - com redução do nível de atividade consistente com a obtenção de uma dada meta inflacionária.

$\mathrm{Na}$ ausência dos arranjos institucionais do crédito direcionado, não há garantia de que o aumento do desemprego ou da capacidade ociosa irá gerar uma resposta estabilizadora de redução das taxas de juros longas de mercado. Primeiro, porque o BC pode não ter espaço para redução da Selic, por paridade de juros. Segundo, porque uma redução da Selic e de sua expectativa futura pode ser neutralizada por elevação dos prêmios de risco requeridos, capaz de dominar a formação dos juros de mercado de longo prazo.

$\mathrm{O}$ efeito direto de eventual encarecimento do custo do crédito do BNDES, via queda da demanda por investimento, pode ser imaterial, em alguns contextos, sob a dinâmica da inflação, relativamente aos efeitos transmitidos via canal do câmbio sobre custos, margens e preços nos setores comercializáveis. Entre outras razões, isso explica por que é inadequada a argumentação que justifica a proposta de indexação automática do custo dos créditos do BNDES ao mercado secundário das NTNB-s de 5 anos enfatizando os supostos efeitos "redistributivos" sobre a ótica do custo de capital, acentuando uma clivagem, mais retórica do que real, entre os "privilegiados" que têm acesso e a massa dos excluídos ao crédito do BNDES.

É essa a ideia subjacente ao argumento que compara o crédito do BNDES à "meia entrada" de estudantes em eventos culturais, algo que tem se mostrado potente política e retoricamente ${ }^{12}$. Ele assume que a criação da TLP gerará, quase automaticamente e em qualquer contexto, uma redução estrutural da Selic em magnitude suficiente para gerar um efeito simétrico, sob a ótica da demanda agregada, capaz de compensar o impacto diretamente restritivo da elevação do custo de capital dos tomadores do BNDES sobre o investimento.

Nesse mundo abstrato, a indexação do custo do BNDES a curvas de mercado - na prática, pouco líquidos e profundos, concentrados em número restrito de investidores institucionais locais e internacionais - geraria efeito de redução horizontal do custo de capital, via queda da Selic, para todos os tomadores, como contrapartida ao efeito de majoração do custo de capital dos ditos "privilegiados", que têm acesso ao Banco ${ }^{13}$.

(12) Ver, sobre a utilização da analogia da "meia entrada", a apresentação do BC: https://www.bcb.gov.br/conteudo/homeptbr/TextosApresentacoes/Apresentacao_Painel_Projeto_Spread_Bancario.pdf.

(13) Independentemente das considerações teóricas, vale notar que a ideia de que o BNDES fornece "crédito a privilegiados" ou a "escolhidos" não bate com um dado simples: de 2007 a 2014, o Banco apoiou 804 das 1.000 maiores empresas brasileiras Ver slide 27 disponível em: https://web.bndes.gov.br/bib/jspui/bitstream/1408/6623/1/Luciano\%20Coutinho BNDES\%202003-2015.pdf. Ademais realizou mais de 5,8 milhões de operações de 2011 a 2016 (relatórios anuais), majoritariamente com micro, pequenas e médias empresas, mediante produtos de grande capilaridade, como o cartão BNDES, ou usando a atratividade da TJLP para modular incentivos visando induzir os bancos comerciais a ampliar o acesso das pequenas empresas as linhas da Finame. 
Porém essa simetria idealizada deixa de existir caso se considere a possibilidade dos juros locais de mercado serem mantidos em patamares elevados, rígidos à baixa, por longos períodos. Caso o patamar requerido por paridade descoberta de juros seja superior ao nível consistente com a obtenção do equilíbrio interno, a existência de mecanismo institucional que faculte a blindagem do núcleo mais produtivo do investimento faz sentido para minimizar os estragos de um "equilíbrio de juros elevados".

Tal quadro é consistente com a ampla evidência empírica que indica a centralidade do câmbio como mecanismo de transmissão da política monetária no Brasil e a baixa sensibilidade a variações marginais na demanda agregada ${ }^{14}$. À luz de tal histórico e dos riscos externos e internos que podem impactar tal "piso" na formação dos juros domésticos básicos, não parece prudente a estratégia de amarrar as mãos dos formuladores das políticas monetárias-creditícias, destruindo um mecanismo que oferece a faculdade, e não a obrigação, de mitigar os efeitos do equilíbrio de juros altos sobre o núcleo mais produtivo da formação de capital.

Não é o BNDES que promove uma competição desleal no mercado financeiro, dificultando sua operação no longo prazo, mas sim os próprios juros altos.

\subsection{Juros altos e desenvolvimento de um sistema privado de crédito e de capital}

O fator mais relevante para o florescimento dos mercados privados de crédito e de capital, com papel destacado no financiamento do investimento produtivo, é a transição do atual regime de taxas de juro altas para um cenário de normalização da estrutura a termo das taxas de juros em moeda local.

A queda dos juros de mercado é o mais poderoso fator de alteração nos incentivos aos investidores, que serão impelidos a ampliar os riscos de mercado e de crédito em suas carteiras para alavancar seus retornos esperados.

O sistema financeiro comercial tem um custo de oportunidade imbatível: juro alto, de curtíssimo prazo (1 dia), operando em geral em instrumentos pós-fixados indexados a taxa do overnight e com a segurança dos títulos públicos federais (TPFs). Nesse contexto, a demanda por títulos públicos de prazos mais longos e prefixados, como os de cinco anos, é menos relevante e mais volátil.

A atrofia das fontes privadas no financiamento de longo prazo é o resultado de deformação institucional grave, expressa na indexação de grande parte da riqueza financeira à taxa do overnight, cuja meta estabelecida pelo Comitê de Política Monetária (Copom) é perseguida diariamente pelo BC. Isso não ocorre com as taxas de títulos mais longos, o que os tornam mais voláteis, com seus preços flutuando em função das expectativas quanto à evolução futura da própria Selic, acrescido do prêmio requerido para induzir o investidor marginal a carregar títulos mais intensivos em risco de mercado em carteira de maior duration.

(14) Ver Modenesi e Araújo (2013). 
Essa institucionalidade da indústria de fundos impede que os gestores ancorem suas decisões de carteira em avaliação dos fundamentos sobre o nível de prêmio adequado para assunção do risco de juros, percebido em horizonte de maturação de médio e longo prazo. Tal viés inibe a constituição de posições compradas em instrumentos de elevada duração, como é comum em mercados mais maduros ${ }^{15}$.

A indexação ao CDI reduz o incentivo para gestor expressar eventual avaliação baixista sobre o curso futuro das taxas de juros. Isso porque ele pode ser punido pela volatilidade de mercado, via indução de resgastes líquidos desencadeados pela marcação a mercado de posições mais intensivas em risco.

Como as cotas têm liquidez imediata, a indústria avalia o desempenho de seus gestores pelo desvio de curto prazo dos retornos observados, após sua marcação a mercado, em relação à taxa do overnight (o retorno livre de risco de crédito e de mercado). Estimula-se a adesão a estratégias defensivas de alocação, ancoradas em LFTs, ativos de crédito privado indexados ao CDI ou operações compromissadas, de duration quase zero.

Todos têm incentivos para manter alocação defensiva em ativos de baixa duração, em parte porque todos os demais assim o fazem. O mercado se aprisiona num "equilíbrio de Nash" de péssima qualidade alocativa, destruidor líquido da demanda por duration por unidade de poupança financeira - expressando-se no encurtamento dos passivos bancários e no baixo apetite por ativos em taxas fixas de prazos maiores, gerando severo racionamento de crédito de longo prazo em fontes de mercado, que afeta a equação de funding dos projetos de investimento.

A indexação ao CDI desestimula os gestores com visão baixista sobre o curso futuro das taxas de juros de expressar essa avaliação por meio da aquisição de ativos de elevado prazo médio ponderado (duration).

A liquidez diária oferecida por esses produtos financeiros é parte indissociável desse problema institucional que inibe a demanda por risco de mercado - ainda que o perfil das necessidades intertemporais do investidor-cotista muitas vezes possa ser compatível com alocação de uma fração maior de sua riqueza em ativos de elevada duração e generosos prêmios de risco.

Tal institucionalidade deforma a estrutura das preferências dos investidores locais em relação ao risco, reduz a demanda por duração por unidade de poupança financeira e, assim, pressiona os prêmios de risco implícitos no custo de carregamento da dívida pública para qualquer estratégia selecionada de gerenciamento do perfil de prazos e taxas dos passivos sob

(15) Outro exemplo de distorção institucional nos incentivos é visto nas regras de tributação dos instrumentos de renda fixa, que vinculam alíquotas marginais decrescentes aos rendimentos auferidos por pessoas físicas, diretamente ou via indústria de fundos, ao prazo dos instrumentos financeiros ou ao período de seu carregamento em carteira, e não à sua duration média. Tais regras, além de inibirem a demanda por instrumentos com risco de mercado, reduzem o incentivo ao uso de estratégias de gestão de recursos intensivas em negociação, inibindo a venda dos ativos e o desenvolvimento de um mercado secundário de títulos privados. 
administração do Tesouro. Ela contamina o custo de capital das empresas em base quase horizontal, ao mesmo tempo em que aprofunda a severidade do racionamento de crédito de longo prazo. É ocioso dizer que a indexação dos ativos financeiros às taxas do overnight obstrui a potência da política monetária, via o dito "efeito riqueza", posto que torna o valor de parte relevante dos ativos financeiros domésticos insensível a mudanças na estrutura a termo das taxas de juros de mercado ${ }^{16}$.

Trata-se de uma armadilha. No regime de juros elevados, as taxas longas lastreadas na dívida pública prefixada acabam sendo mais voláteis do que as expectativas subjacentes, pois esses mercados são pouco profundos. E esses vértices mais longos permanecem com baixa profundidade, em parte, por serem esses mercados mais voláteis, o que afugenta a demanda por duração dos investidores, constrangidos pelos limites de value at risk em suas carteiras.

O argumento teórico original do racionamento de crédito como expressão do equilíbrio de portfólio bancário em um quadro de assimetrias de informação e riscos derivados da existência de seleção adversa ${ }^{17}$ - constitutivos da relação de crédito, baseada na confiança relativa à capacidade de repagamento futuro - não são suficientes para explicar o fenômeno do racionamento de crédito de longo prazo na intensidade observada no Brasil. A severidade atípica do racionamento em nossa realidade decorre das limitações nos passivos bancários e da baixa intensidade na demanda por duração nos portfólios privados - atingindo o racionamento de crédito de longo prazo junto às fontes de mercado, inclusive, as maiores e melhores empresas operando no país.

O patamar dos juros básicos amplifica o grau de aversão ao risco implícito nas decisões de carteira de bancos e investidores. Esse efeito acarreta em alta seletividade, elevação dos spreads de break even e severo racionamento de crédito de longo prazo operado por fontes privadas - afetando a disposição dos emprestadores a contratar o crédito de prazos mais longo ou causando desinteresse dos próprios emissores em sancionar o patamar de spreads exigidos pelos investidores - acarretando na concentração da riqueza financeira em instrumentos de baixa duração.

Em suma, em regime de juros elevados, o grau de aversão ao risco dos detentores da riqueza é ele próprio uma função do patamar das taxas de juros livres de risco, que "normaliza" o prêmio requerido pelos investidores nos diversos ativos.

\subsection{A flexibilidade da gestão da TJLP e a potência da política monetária}

Se soa inverossímil que a operação da TJLP pelo BNDES seja a causa dos juros altos e da atrofia do mercado privado de crédito e de capital, não é difícil notar que esse sistema permite mitigar os efeitos deletérios dessa falha macroeconômica estrutural sobre o investimento produtivo.

(16) Lopes (1998).

(17) Stiglitz e Weiss (jun. 1981). 
A TJLP era fixada pelo Conselho Monetário Nacional, composto pelos ministros da Fazenda e do Planejamento e pelo presidente do Banco Central. A Selic é definida pelo BC, que persegue diariamente a meta fixada pelo seu Comitê de Política Monetária (Copom). Logo, ambas as taxas são arbitradas pela equipe econômica.

O crédito ao investimento - que, hoje, gera emprego e renda e, amanhã, eleva a capacidade produtiva e a produtividade, ampliando as possibilidades de crescer sob baixa inflação - pode ficar mais protegido dos juros persistentemente altos.

A decisão sobre o nível adequado de cada taxa (Selic e TJLP) depende das condições específicas de cada conjuntura e pode ser tomada livremente pela equipe econômica, calibrando o custo fiscal e a prioridade que se deseja dar ao investimento produtivo frente ao capital de giro e o consumo das famílias ${ }^{18}$.

As autoridades no CMN podiam, quando quisessem, aproximar ou equalizar a TJLP à Selic. O custo fiscal direto dos empréstimos do Tesouro ao BNDES seria reduzido ou zerado, mas sem abrir mão de um instrumento de mitigação do racionamento de crédito de longo prazo às empresas.

A equipe econômica podia calibrar o nível do "subsídio" de natureza corretiva visando melhor alinhar os retornos social e privado de projetos intensivos em externalidades, porém garantindo maior grau de correlação entre as taxas relevantes para ajustar o custo de financiamento ao capital de giro e ao investimento às empresas - (Selic e TJLP), visando garantir que "remem juntas" à luz dos objetivos de curto prazo das políticas monetária e creditícia. Tal discussão possui caráter conjuntural e depende da avaliação das autoridades sobre a combinação mais adequada em cada contexto.

A ação de um banco de desenvolvimento em escala sistemicamente relevante também contribui para maior eficiência na intermediação financeira na medida em que ele opere mais próximo da análise neutra ao risco, tendendo a gerar spreads de break even menores na provisão de crédito às empresas, além de permitir ação anticíclica que limita a excessiva volatilidade

(18) Os defensores da MP 777 argumentam que ela amplia a transparência e o caráter democrático da alocação de subsídios - posto que elimina o subsídio implícito na TJLP, mas não veda o subsídio explícito, via Orçamento Geral da União (OGU), contabilizado como despesa primária da União. Para dar contas das externalidades, uma opção frequentemente mencionada é a concessão direta de subsídio ao crédito para o investimento, via alocação orçamentária. Na prática isso significaria sua virtual eliminação, considerando o espaço exíguo para as despesas primárias no contexto da PEC do teto dos gastos agravando rigidez institucional para ativação de um dos motores autônomos para recuperação do crescimento, via investimentos em infraestrutura, por exemplo, mesmo quando o retorno social dos projetos superar largamente seu retorno privado. É claro que o OGU é um instrumento democrático de alocação de recursos públicos. Mas nem tudo que deixa de passar por ele viola os princípios democráticos. Por exemplo, os evidentes efeitos fiscais da política monetária (Selic) ou os custos de carregamento de reservas cambiais não passam. E nem devem, sob pena de comprometer a capacidade das autoridades, proverem com efetividade e eficiência um bem público fundamental como a estabilidade de preços. Afinal, o BC deve ter amplos graus de liberdade para manter a inflação sobre controle e gerar condições favoráveis ao crescimento. A validação democrática das decisões de política monetária, acarretando em custos fiscais inequívocos, sem transitar pelo OGU, decorre da delegação congressual, auferida por lei ao BC, renovada pela eleição periódica do chefe do executivo. A política creditícia, em particular pela afinidade intrínseca, deve ser vista de forma integrada às políticas monetária e cambial. A taxa que regula o custo do financiamento ao investimento produtivo em nossa institucionalidade faz parte do arcabouço de instrumentos das políticas monetária/creditícia que será enfraquecido caso vingue a ideia de colar automaticamente a TLP na NTN-B de cinco anos. 
das condições de acesso ao crédito para o financiamento de projetos de longo prazo ao longo do ciclo.

Afinal, como um banco de desenvolvimento, com fontes de recursos e projetos de longo prazo, o BNDES atua sustentavelmente com um menor grau de aversão ao risco do que observado no sistema financeiro comercial privado.

Isso se expressa em metas de rentabilidade inferiores, embutidas em seus menores spreads, ainda assim compatíveis com a remuneração adequada dos riscos de crédito e de mercado em carteira, e com a preservação e crescimento de sua base de capital. Ao viabilizar menores spreads de break even, a ação do BNDES contribui para ampliar a eficiência na provisão dos serviços de intermediação financeira, conforme pode ser visto no gráfico a seguir.

De 2011 a 2016, usando dados de demonstrações financeiras, a margem bruta de intermediação financeira (spread total) do BNDES foi em média de $2 \%$ a.a. No mesmo período, o spread médio do sistema financeiro às empresas nas operações de crédito livre, conforme metodologia do BC, foi de $14,6 \%$ a.a. ${ }^{19}$

Gráfico 3

Spreads de Crédito às Empresas - \% a.a.

BNDES vs. Operações de Crédito Livre às Empresas

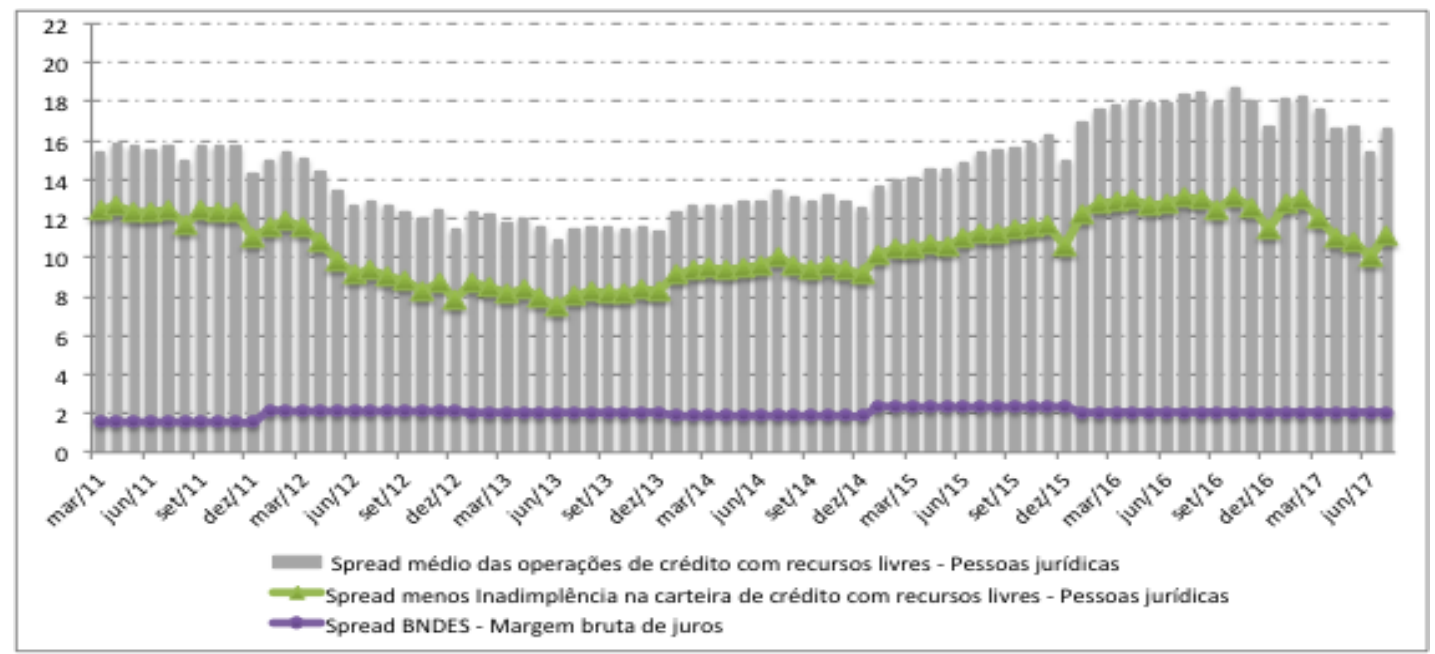

Fonte: BACEN - spread e inadimplência apurados nas operações de crédito livre as empresas e BNDES - margem bruta de juros, a partir de dados contábeis (para 1ํㅗ semestre de 2017, extrapolação da margem bruta média observada em 2016).

(19) O spread médio do crédito livre às empresas no período de janeiro de 2011 a julho 2017 (14,6\%), quando subtraído pela inadimplência observada nesse segmento, gera margem líquida estimada da ordem de 10,6\% a.a. Esse patamar representa mais de 5 vezes o valor apurado da margem bruta de juros do BNDES no período. Tais números permitem concluir que o diferencial observado entre os spreads não decorre fundamentalmente dos perfis de risco dos tomadores do BNDES relativamente aos tomadores do crédito livre, como argumentam os autores que enfatizam os impactos de suposta seleção adversa em razão da maior atratividade dos financiamentos do Banco. Tal diferença tampouco decorre de fatores tributários, pois o BNDES recebe o mesmo tratamento das instituições financeiras privadas. 
Nesse sentido, é eloquente a comparação entre o esforço contracíclico brasileiro - via empréstimos em TJLP do Tesouro Nacional ao BNDES - com a política de afrouxamento monetário ("quantitative easing") usada em países desenvolvidos para combater os efeitos da crise financeira internacional a partir de $2008^{20}$.

Os bancos centrais desses países inflaram seus balanços operando para "amassar" a estrutura a termo da curva de juros livre de risco pela aquisição em grande escala de ativos de elevada duration. Entretanto, os bancos privados e demais atores no mercado de capitais anularam parte de seus efeitos ao buscar estratégias de desalavancagem e redução dos riscos em seus balanços.

Agregadamente, esse movimento operou como fator limitador da efetividade da política monetária expansiva pelo canal de crédito, em função da elevada seletividade no acesso, e da ampliação endógena dos spreads praticados na concessão de financiamentos novos às empresas sobre a curva livre de risco. Tal circunstância operou como fator limitador da recuperação nos países centrais.

Assim, a ação da política monetária via canal de crédito, ao invés de perder, ganha potência em regimes marcados pela presença relevante de instituições de desenvolvimento na combinação da oferta de crédito de longo prazo às empresas.

A TLP, por sua vez, pode reduzir o controle das autoridades econômicas sobre a demanda agregada. Uma taxa como a NTN-B de cinco anos tem seu componente prefixado influenciado pelo caráter procíclico dos prêmios de risco, especialmente em momentos de stress de mercado - típico de dinâmicas de overshooting.

A preocupação se agrava considerando a baixa/média profundidade dos mercados desses títulos, marcados por forte presença de investidores estrangeiros - que atuam frequentemente com comportamento de "manada", respondendo a sinais fora do controle das autoridades locais - e do baixo número de grandes investidores institucionais locais com apetite por duration.

Corre-se o risco de ver os juros subirem, contaminando o custo do investimento apoiado pelo BNDES, por elevação de aversão ao risco dos investidores, quando a economia estiver em perspectiva de desaceleração e submetida a maior stress financeiro. E na fase expansiva de vê-los caírem na euforia de um ciclo especulativo que comprima os prêmios de risco dos ativos locais.

Ao contrário do defendido pelos autores da proposta, a potência da política monetária, via canal do crédito - entendida como a capacidade das autoridades afetarem a demanda via modulação da estrutura a termo do custo do crédito - seria reduzida com a mudança. A ponta longa da curva de juros, formada em segmentos de baixa profundidade e elevada concentração em poucos investidores institucionais, regularia o custo do crédito de longo prazo, deixando de estar sob o controle direto das autoridades.

(20) Mehrling (2010); Bernanke (2013). 
Há outro problema. Ao colar a TLP na NTN-B, indexada ao IPCA, gera-se incentivo financeiro para que as empresas adiram a práticas formais e informais de indexação dos preços à inflação passada. Com isso aumenta-se a inércia inflacionária, resultado da mudança de perfil dos passivos financeiros de boa parte das empresas. A indexação dos passivos à inflação passada pode afetar a formação de preços das empresas endividadas no BNDES, o que tende a reduzir a efetividade da política monetária.

Quanto à necessidade de dar maior previsibilidade à taxa de juro de longo prazo, seria suficiente mudar a TJLP de taxa variável para fixa na data de contratação - o que ademais tende a ajudar à política monetária, por acarretar em maior intensidade da resposta de curto prazo do investimento aos movimentos do custo do funding do BNDES ${ }^{21}$. Indexar o custo de apoio ofertado pelo BNDES a títulos de mercados pouco profundos transfere sua maior volatilidade ao custo do financiamento do investimento ${ }^{22}$. Como banco público e de longo prazo, o BNDES pode e deve atuar para mitigar os exageros e as propensões procíclicas das finanças privadas.

Uma alternativa seria manter a formatação da TLP, com a transição para um modelo de funding institucional remunerado a taxa fixas e não mais flutuantes, mas conferindo ao CMN o poder de aplicar redutores, horizontalmente ou focado em atividades especificas, relativamente à taxa de mercado de referência. Assim, seria preservada ao CMN a prerrogativa (não a obrigação), de modular a "estrutura a termo" (curva de juros conforme o prazo) do custo de funding, ampliando, ao invés de reduzir, a potência da política monetária pelo canal do crédito.

Nesse desenho institucional seriam mantidos os benefícios decorrentes da transição para um regime de taxas fixas e, conforme as necessidades e a depender da avaliação do espaço fiscal em cada conjuntura, seria facultado às autoridades monetárias-creditícias:

i) filtrar eventual volatilidade excessiva da NTN-B de cinco anos, evitando a sua transmissão automática ao custo do crédito de longo prazo ao investimento, em contextos de nervosismo de mercado;

(21) Uma mudança de taxa a ser carregada por toda a vida do contrato possui maior tração sobre o custo de funding do projeto, e, logo, sobre o timing de uma decisão de investimento, do que uma mudança em uma taxa flutuante, cujo efeito está restrito ao custo corrente, por 3 meses, de servir uma dívida em TJLP. Migrar de taxa flutuante para fixa é positivo, sob a ótica da previsibilidade do custo e da tração da política monetária. O que não se justifica é a indexação automática e inflexível a uma referência de mercado potencialmente volátil e carregada de elevados prêmios de risco, com a eliminação de qualquer espaço para a alocação de subsídios implícitos na condução das políticas monetária/creditícias, mesmo para atividades intensivas em externalidades.

(22) Uma diferença importante que precisa ser estabelecida diz respeito ao fato de que, em conjunturas de stress de mercado, a taxa de retorno apurada em mercado secundário dos títulos públicos de longo prazo não traduz o custo que o tesouro efetivamente incorre na captação de recursos - posto que em meio a processos de "overshooting" o Tesouro tende a interromper as emissões primárias de papéis de maior duration, sem aceitar travar o custo associado a tais momentos de maior nervosismo de mercado. 
ii) conceder um incentivo horizontal, visando estimular o investimento em momentos de grande capacidade ociosa e desemprego involuntário, em particular em cenário contingente de forte elevação dos prêmios de risco implícitos nos preços dos títulos públicos de longo prazo, correlacionados frequentemente a conjunturas de desaceleração e estresse fiscal-financeiro ${ }^{23}$;

iii) apoiar setores e atividades intensivas em externalidades para proporcionar uma redução focalizada do custo de financiamento de forma a alinhar o retorno privado ao retorno social dos projetos;

iv) preservar graus de liberdade para políticas de crédito em articulação a outras políticas industriais e de desenvolvimento, orientadas a transformação das estruturas produtivas, visando a obtenção de ganhos de produtividade não passíveis de emergir espontaneamente com base em dinâmicas financeiras privadas, reguladas exclusivamente por preços e sinais de mercado.

\subsection{A convergência dos custos de mercado e do funding institucional e o papel de um banco de desenvolvimento}

O caminho virtuoso para a convergência entre o custo do funding institucional do BNDES e a Selic (ou qualquer outra taxa aplicável ao custo de captação do Tesouro) precisa ser viabilizado por uma agenda que permita a redução sustentável e não inflacionária da segunda, e não pelo estrangulamento do investimento produtivo.

Inverter o argumento, fazendo crer que a ausência do BNDES propiciará por si só o florescimento de mercados privados de crédito e de capital profundos e maduros, desafia o bom senso e a experiência histórica.

Mais razoável, em particular considerando a recessão dos últimos anos, é ajustar o papel do BNDES, com foco progressivo nas atividades intensivas em externalidades. Na medida em que a atividade econômica se recupere, a Selic caia e as fontes privadas se mostrarem aptas a assumir maiores protagonismos no financiamento ao investimento em condições aceitáveis de custo, prazo e volume, o BNDES poderá ter um papel diferente, ainda que não necessariamente menos relevante.

(23) Assim, protege-se a economia dos cenários em que a reação procíclica observada nos prêmios de risco exigidos em tais mercados de títulos seja intensa o bastante para bloquear dinâmicas financeiras estabilizadoras que deveriam levar a um ajuste endógeno virtuoso de ampliação do investimento privado induzido pela redução líquida das taxas de juros longas em resposta a desequilíbrio persistente nos mercados de bens e de trabalho. A faculdade das autoridades reduzir diretamente o custo do funding ofertado pelo BNDES ao investimento, em cenários de forte aversão ao risco das fontes privadas, deve ser mantido, ainda que usado com parcimônia em função das restrições fiscais, como uma espécie de "seguro" institucional contra dinâmicas financeiras contingentes potencialmente instáveis e desestabilizadoras dos mercados de bens. Deve-se manter tal flexibilidade, mesmo que se entenda adequado impor, como regra geral, o princípio de que o custo do funding de longo prazo para atividades não geradoras de externalidades deva progressivamente convergir para o custo de captação do Tesouro em tais prazos, em condições normais de funcionamento dos mercados. 
É preciso ainda ter em conta que um BD - mesmo que atue somente como ferramenta de correção de falhas de mercado clássicas, decorrentes da existência de atividades intensivas em externalidades, com retorno social maior que o retorno privado - deve ter algum tipo de vantagem de custo, seja por uma fonte de recursos captada a taxa mais baixa ou algum grau de imunidade tributária ${ }^{24}$.

$\mathrm{O}$ ataque ao atual sistema acaba por ampliar o poder de mercado do sistema financeiro comercial. Há muito ruído e uma cortina de fumaça em torno das razões do juro alto. $\mathrm{O}$ insuspeito André Lara Rezende admitiu recentemente a falta de consistência nos diagnósticos sobre os elevados juros de mercado no Brasil ${ }^{25}$.

Tudo isso reforça a aversão ao risco e perpetua a combinação de lucros elevados e risco baixo para os bancos comerciais, tão lucrativa mesmo em tempos fortemente recessivos, em detrimento do financiamento de longo prazo. Qualquer que seja o entendimento sobre as razões do juro alto não soa adequado culpar à ação dos mecanismos desenvolvidos para mitigar seus efeitos deletérios sobre o investimento.

Além disso, admitir que o subsídio via crédito não deva ser indiscriminado não significa que qualquer subsídio seja indesejável. Assim, seria mais eficiente ancorar o debate sobre a formação do custo do funding do BNDES - calibrando o nível e o foco desejável do "subsídio" em relação às referências de "mercado" - em avaliações mais qualificadas da lacuna potencial entre os retornos privado e social nas áreas de ação que se entenda prioritárias para o BNDES $^{26}$. Do contrário, seria optar por destruir o excedente econômico gerado pela correção de tais falhas de mercado clássicas em nome apenas de uma retórica vazia e deletéria de "austeridade" e "responsabilidade" fiscal.

Por exemplo, Alexandre Scheinkman, em palestra em julho de 2016 no BNDES $^{27}$, mostrou estimativa de que o retorno social de investimentos em P\&D nos EUA são da ordem de $40 \%$ a $60 \%$ a.a. Alocar subsídios para viabilizar tais atividades ou investimentos

(24) É razoável que bancos de fomento também tenham vantagens regulatórias, que permitam a eles tomar mais risco do que o previsto nas normas e nos indicadores de prudência bancária. Por um lado, isso é necessário porque o apoio a projetos intensivos em externalidades significa a necessidade de tomar mais risco. Afinal, a dificuldade de internalizar benefícios do projeto em suas receitas é claramente uma fonte de risco extraordinário. Por outro, por não serem movidos pela lógica da maximização privada - isto é, não tomam riscos adicionais pela perspectiva de lucros extraordinários, mas pelos ganhos sociais que trazem - os BDs tendem a não sofrer dos riscos de atuação procíclica que impõem um controle mais estrito da indústria financeira pelas autoridades monetárias. Ainda assim, cabe ressaltar que o BNDES está sujeito a exatamente a mesma regulação prudencial imposta aos bancos privados assim como as mesmas regras tributárias.

(25) http://www.valor.com.br/cultura/4834784/juros-e-conservadorismo-intelectual.

(26) Seria possível aprimorar o funcionamento do BNDES como uma ferramenta de correção de tais falhas de mercado clássicas mediante reforma nos processos internos de análise e aprovação dos projetos, vinculando-se diretamente à precificação do apoio financeiro / alocação de subsídios aos projetos a um rating de externalidades, a ser construído e validado mediante análise técnica e aprovado em instância colegiada - análogo ao aplicado sob a ótica da avaliação e precificação do risco de crédito - o custo financeiro inferior ao mercado seria alocado para atividades percebidas tecnicamente como sendo mais intensivas na geração de externalidades.

(27) Disponível em: http://www.bndes.gov.br/wps/wcm/connect/site/f3e0d954-9796-4782-952e12d6588e9708/Scheinkman_Apresentacao.pdf?MOD=AJPERES\&CVID=1tJ8xos\&CVID=1tJ8xos. 
em infraestrutura ou intensivos em ganhos de aprendizado, que fertilizam outros setores, não deveria ser visto como custo líquido para a sociedade, mas sim como forma de ganhar eficiência, capaz de gerar excedente econômico que melhora as contas fiscais e alarga as bases do desenvolvimento.

Variados desenhos são possíveis para os BDs, que envolvem, por exemplo: (i) um papel contracíclico, o que exige operar correntemente no mercado em escala relevante para formar uma ampla rede de relacionamentos comerciais que o faça capaz de suprir com a agilidade requerida eventuais lacunas derivadas da pro-ciclicidade das fontes privadas; (ii) atuar em renda variável para apoiar projetos de maior risco (empresas de base tecnológica, internacionalização de grupos nacionais etc.); ou iii) apoiar as exportações de bens de mais alto valor agregado.

Esses desenhos geram intenso debate. Mas a sua versão mais básica é amplamente aceita: um BD deve financiar projetos de altas externalidades, que tenham benefícios sociais não capturados pela rentabilidade privada via preço, como infraestrutura, inovação e meio ambiente. E, mesmo nesse caso mais restrito, é indesejável a proposta de convergir a TJLP e a Selic pela elevação da primeira.

\subsection{Para além das externalidades}

É consensual que no caso da existência de externalidades - isto é, benefícios de um projeto que não são capturados pelo empreendedor via receitas - um banco de desenvolvimento deve atuar para viabilizar os projetos.

Por exemplo, na execução de grande parte dos investimentos no setor de infraestrutura - frequentemente licitados mediante leilões competitivos para apuração da tarifa aplicável aos serviços a serem concedidos - os "subsídios" creditícios alocados via custo e prazo do funding do BNDES são considerados nos processos competitivos, afetando o resultado do leilão.

As condições de funding afetam a tarifa de provisão das diversas infraestruturas, que são demandadas intensivamente em várias cadeias de produção. Os subsídios alocados via crédito de longo prazo vinculam-se diretamente ao objetivo de sustentação da modicidade tarifária e operam como veículo redistributivo em favor dos usuários das infraestruturas objeto de concessão. O "subsídio ao BNDES" deve ser entendido nesses casos como algo apropriado pelos demandantes finais desses serviços - sendo muitas vezes necessário para dar viabilidade a projetos com baixa taxa de retorno privado e alta taxa de retorno social.

Considerando ademais i) que os spreads do BNDES são usualmente inferiores aos spreads médios praticados na intermediação bancária privada, ii) a hipótese (heroica) de que haveria apetite e capacidade das fontes privadas para absorver integralmente o deslocamento na demanda por financiamentos providos pelo banco, mesmo em empreendimentos de grande envergadura e iii) que eventual redução do apoio do BNDES deve pressionar o custo de endividamento dos projetos, observar-se-ia ampliação do custo do endividamento, redução do 
prazo e duration média das dívidas, transferindo para o investidor privado riscos adicionais de refinanciamento, e decorrentes da maior volatilidade das taxas de juros de curto prazo em moeda local ao longo da vida dos projetos, além de induzir maior grau de endividamento externo, o que vulnerabiliza financeiramente os empreendimentos com baixa geração de receitas em moeda estrangeira e, logo, pouca capacidade natural de absorção dos riscos cambiais.

Tais efeitos oneram diretamente o custo do endividamento. Eles são transmitidos de forma amplificada, sob a ótica do custo médio ponderado de capital dos projetos, ao reduzirem a capacidade de alavancagem, em função da redução do fluxo de caixa livre passível de ser alocado como garantia em estruturas de project finance. A substituição do BNDES por fontes de mercado acarretaria no encarecimento direto do componente de dívida na estrutura de fontes dos projetos. Ao limitar o espaço para a alavancagem ele gera efeito de segunda ordem de ampliação do componente de equity requerido para viabilizar os empreendimentos, com custo implícito superior às dívidas de mercado. Esse mecanismo amplifica o efeito da substituição do BNDES por fontes privadas no mercado de crédito sobe o custo médio ponderado de capital dos projetos. Tal impacto pode ser muito superior à simples diferença histórica entre a TJLP e a Selic, posto que envolve o diferencial de spreads de crédito e o equity premium $^{28}$.

O ganho de eficiência trazido pelo BNDES na alocação dos recursos decorre da função clássica de um BD visando melhor alinhar a taxa de retorno social e privada de projetos intensivos em externalidades. Mas ele decorre também do efeito da flexibilização das restrições de crédito existente nas fontes privadas sob o perfil do investimento executado, via modulação das condições de provisão de funding.

Mesmo para quem crê na existência de mecanismos macroeconômicos autocorretivos, capazes de empurrar de forma mais ou menos automática a economia para o equilíbrio de pleno emprego, em cenário contrafactual de redução drástica da ação do BNDES, seria forçoso reconhecer que tal configuração alocativa tenderia a ser marcada pela maior intensidade do racionamento de crédito de longo prazo em moeda local.

Dessa forma, o mesmo volume de investimento agregado, compatível com a restrição da taxa de poupança em pleno emprego (incluindo nível prudencial de absorção de poupança externa), seria obtido com maior pulverização da inversão em maior número de projetos

(28) Por esses motivos o BNDES tende a ser veículo fiscalmente mais eficiente para alocação de subsídios de natureza corretiva - visando melhor alinhar o retorno privado ao retorno social dos projetos intensivos em externalidades - do que seria observado com a utilização de fontes privadas de financiamento conjugadas à celebração de contrato via Parceria-Público-Privada (PPP). O valor de contraprestação orçamentária direta que seria necessária em esquema de PPP para neutralizar o impacto do ajuste no mix de fontes dos projetos - com substituição do BNDES por fontes de mercado - sobre a tarifa do serviço concedido, tenderia a ser bastante superior ao valor do subsídio implícito alocado via crédito do Banco - medido pela diferença entre a TJLP (ou taxa fixa) e a Selic. Tal fato deve ser agravado caso seja considerado que o valor presente de uma determinada contraprestação fixa a ser paga periodicamente pelo Tesouro tenderá a ser descontado pelo investidor por taxa que embutirá prêmio relativo ao risco percebido de contingenciamento orçamentário, enquanto a taxa de desconto relativa à avaliação do valor presente do diferencial esperado do custo de funding para a empresa deve ser a taxa livre de risco. 
demandantes de menor volume de inversão unitária. Exemplo típico seria na geração de energia fazer PCHs e outros projetos de menor escala e menor eficiência com fontes privadas em vez de concretizar grandes projetos de UHE com financiamento do $\mathrm{BNDES}^{29}$.

A ampliação das restrições financeiras em moeda local, ao afetar a viabilidade da execução de projetos intensivos em escala, tenderia a reduzir o crescimento da produtividade dos fatores derivado do mesmo volume agregado de investimento.

O enfrentamento da severidade do racionamento de crédito de longo prazo pela ação corretiva do BNDES tende a gerar efeitos positivos sobre a eficiência na alocação de recursos, mesmo em pleno emprego. Tais resultados podem ser observados mesmo que a ação do banco no limite não gere adicionalidade líquida sobre o volume dos investimentos executado na economia - restritos, nesse caso particular e apenas nele, pelo volume agregado de poupança.

A flexibilização da restrição de crédito de longo prazo às firmas melhora a alocação de recursos, ainda que os projetos não sejam geradores de externalidades relevantes, caso em que o retorno é integralmente apropriado internamente às empresas. Projetos podem ser inviabilizados em favor de opções demandantes de menor volume de inversão, ainda que possuidoras de menor retorno potencial por unidade de capital aplicado, por serem mais palatáveis sob a ótica da tolerância ao risco das fontes de crédito privado, por terem menor prazo de repagamento (pay back) e envolverem menor volume de investimento unitário.

Logo, é equivocada e deletéria ao crescimento de longo prazo a visão que procura circunscrever a ação do BNDES a projetos intensivos em externalidades, que gerem divergência relevante da taxa de retorno social e privada dos empreendimentos - ainda que sua ação nesses casos seja prioritária.

Além disso, em cenários de ampla ociosidade dos fatores de produção e elevada aversão ao risco das fontes privadas, a adicionalidade ao investimento derivada da ação do BNDES, ao sanar a falha de mercado expressa no severo racionamento do crédito de longo prazo junto as fontes privadas, tende a produzir efeitos mais potentes do que os observados em cenários de plena utilização dos recursos.

Nesses casos, prevalece a causalidade tipicamente keynesiana em que a variação autônoma do investimento - no caso o adicionado pelo enfrentamento do racionamento do crédito de longo prazo pela ação corretiva do BNDES - desencadeia efeitos multiplicadores sobre a renda que, dada a propensão marginal a poupar da comunidade, acarretam na ampliação da massa agregada de poupança, em igual montante ao investimento incrementado.

Com a redução da escala de atuação do BNDES, a intensidade da recuperação do investimento seria desnecessariamente menor do que poderia ser, com renúncia dos ganhos

(29) Evidentemente, podem existir razões para se preferir reduzir a participação das UHE na matriz energética, mas isso não deveria decorrer de uma restrição de fontes. 
fiscais indiretos derivados do efeito multiplicador do investimento incremental, em quadro de ampla capacidade ociosa e desemprego involuntário.

A ação do BNDES mitiga os efeitos das falhas de mercados presentes na intermediação financeira privada, gerando efeitos de adicionalidade sobre o volume e alterando o perfil e a composição do investimento executado. Tal dimensão alocativa é usualmente omitida do debate público sobre o tema, que acaba circunscrito a truísmos contábeis - reiteração da afirmação auto-evidente segundo a qual, tudo o mais constante, se o Tesouro capta recursos a custo maior do que a remuneração direta que recebe do BNDES nos empréstimos, tal ação gera um custo fiscal direto ao Erário.

O problema desse truísmo é que não vale o "tudo o mais constante". É preciso contrapor custos a benefícios potenciais derivados da ação corretiva das falhas de mercado, viabilizada por tais empréstimos, para fazer um juízo racional sobre a pertinência de tal medida. Esse assunto será tratado na próxima seção.

\section{Devolução antecipada dos empréstimos do Tesouro Nacional ao BNDES}

Em dezembro de 2016, o BNDES pagou antecipadamente R $\$ 100$ bilhões ao Tesouro Nacional. Essa antecipação foi alvo de questionamentos acerca de sua ilegalidade, por ferir o artigo 37 da Lei de Responsabilidade Fiscal (LRF). Mas teve parecer favorável do TCU, desde que fosse usado para abater dívida pública. Ainda assim, a MP n 777 prevê em seu artigo $10^{\circ}$ uma autorização legislativa para que novas devoluções possam ocorrer sob o abrigo da legislação.

A discussão, embora tenha aspectos legais e fiscais, envolve principalmente uma decisão acerca do tamanho e das funções de um banco de desenvolvimento.

\subsection{O fetiche da dívida bruta e o tamanho do BNDES}

A antecipação dos empréstimos do BNDES ao Tesouro busca primeiramente gerar efeitos contábeis positivos, relativos à redução da estatística da Dívida Bruta do Governo Geral (DBGG), ainda que tal efeito não traduza melhoria real na posição patrimonial do setor público. A queda da dívida bruta da União tem como contrapartida a baixa de ativo de mesmo valor contábil e elevada qualidade de crédito, os empréstimos ao BNDES.

Além de não alterar a dívida líquida, mesmo a queda da dívida bruta, que foi de 1,6\% do PIB, não muda a sua trajetória, que está associada ao nível da Selic e às perspectivas de crescimento da economia brasileira.

Todavia, a economia política subjacente ao debate público acabou por cristalizar, de forma inadequada, a percepção de suposta robustez técnica da ênfase quase exclusiva depositada, por alguns analistas de mercado e pelas agências de rating, nas implicações diretas de tais empréstimos sobre a trajetória da DBGG. 
Interrompe-se uma discussão mais cuidadosa sobre os impactos de tais empréstimos sobre as contas públicas que considere efeitos sobre a trajetória tanto da dívida bruta quanto da dívida líquida da União.

O foco exclusivo sobre a trajetória da dívida bruta produz distorções relevantes sob a ótica da mensuração da força financeira inerente ao balanço consolidado da União. Esse viés pode ser percebido como análogo à pretensão de avaliar a capacidade de pagamento de uma empresa emissora de títulos olhando apenas o estoque de endividamento e ignorando o volume e a qualidade dos ativos financiados. Tal abordagem equivale à abolição do princípio das partidas dobradas e só pode ser sustentada como expressão de um viés ideológico e de uma aversão quase absoluta ao risco de suposta "opacidade" percebida nas estatísticas fiscais.

O remédio aqui é mais transparência fiscal, e não menos poder de fogo para o BNDES mitigar as falhas de mercado inibidoras do investimento. Que tal avançar na agenda de transparência fiscal mediante uma discussão mais pormenorizada, por exemplo, sobre a utilização do regime de competência para contabilização de eventuais obrigações de subvenção econômica com os bancos públicos, com a incorporação dos passivos apurados em seus balanços, em regime de competência, na estatística de Dívida Líquida do Setor Público?

A resposta oferecida - desconsiderar a dívida líquida como dimensão relevante da execução da política fiscal - "joga fora a criança com a água do banho”. Como corolário dessa distorção, para atingir um objetivo meramente contábil, propõe-se a antecipação dos empréstimos do BNDES que, sob a ótica econômica, aprofunda uma falha de mercado e drena recursos de longo prazo que serão necessários ao apoio da recuperação da inversão, especialmente se as medidas desenhadas com vistas à restauração da confiança tiverem o efeito desejado.

Outro argumento invocado para justificar o foco na dívida bruta é o de que os créditos do BNDES à União devem ser desconsiderados nas estatísticas fiscais por serem haveres ilíquidos, empréstimos de longo prazo de maturação.

Embora o grau de liquidez de créditos de elevada qualidade não seja relevante para fins de avaliar a solvabilidade intertemporal do setor público, ela importa sob a ótica da aferição e da gestão dos riscos financeiros inscritos no perfil das necessidades de rolagem da dívida pública sobre administração do Tesouro.

Porém cabe destacar que eventual decisão de não refinanciamento da dívida vincenda do Tesouro tende a transformar endogenamente a dívida pública mobiliária em poder do público em passivo oneroso do BC. Caso o Tesouro decida não rolar parte dos títulos vincendos ele deverá reduzir suas disponibilidades junto à conta única da União no BC. Ao optar pela não rolagem da dívida, injeta-se reserva bancária diretamente na economia. Tal decisão exige, para garantir a convergência da taxa Selic à meta fixada pelo Copom, que sejam feitas por parte do BC operações simétricas de esterilização. 
O colchão de liquidez na Conta Única define os graus de liberdade que o Tesouro Nacional possui para resistir e, eventualmente, não sancionar a estrutura de prêmio de risco demandada pelos agentes de mercado nos leilões primários de dívida pública, caso estes sejam percebidos como excessivos.

Assinale-se que os riscos de rolagem da dívida pública caíram significativamente no período de crescimento mais forte dos empréstimos da União ao BNDES. A relação entre o volume de recursos na Conta Única relativamente ao fluxo projetado de rolagens da dívida do Tesouro, no horizonte de 12 meses, passou, de cerca de 56\% no início de 2007 para mais de $150 \%$ em marco de 2016.

Não é prudente limitar a tração das medidas voltadas à restauração da confiança sobre o investimento por desnecessária redução da capacidade de empréstimo do BNDES, apenas para melhorar a estatística de dívida bruta a curto prazo, sem que este movimento traduza robustecimento real da situação patrimonial do setor público. É inescapável comparar o apelo dessa proposta ao regresso da dita "contabilidade criativa", visto tratar-se de operação financeira desenhada com foco prioritário na sensibilização da estatística de endividamento, sem de fato acarretar uma melhora efetiva da posição patrimonial da União.

Essa opção se faz ao custo de promover o enrijecimento desnecessário das restrições financeiras que pesarão sob o investimento produtivo na recuperação da atividade econômica, operando como vetor contracionista sobre seu potencial de reação - especialmente, mas não exclusivamente, em setores capital intensivos e fortes geradores de externalidades, como no setor de infraestrutura.

Uma vez considerados os efeitos econômicos e alocativos derivados de tal decisão é plausível imaginar que o efeito fiscal líquido seja negativo, especialmente considerando-se o atual contexto depressivo, com ampla disponibilidade de fatores produtivos ociosos e alta aversão ao risco das fontes privadas de financiamento.

Além do efeito na dívida bruta, decorrem da antecipação dos pagamentos efeitos econômicos reais, derivados da maior limitação da capacidade do BNDES prover funding de longo prazo ao investimento à medida que a economia se recupere.

O BNDES não precisa de novos aportes do Tesouro para manter o seu orçamento de liberações em escala equivalente, em termos reais, ao observado antes do início da crise internacional e da aceleração dos empréstimos do Tesouro em 2009, para apoiar a recuperação do investimento na escala necessária à retomada sustentada do crescimento. Grosso modo, o desembolso nominal de 2008 (R \$ 90,9 bilhões) atualizado para dezembro de 2016, foi de R\$ 150 bilhões, valor próximo das disponibilidades do BNDES para desembolsar em 2017.

Porém, caso os recursos continuem sendo devolvidos antecipadamente haverá um provável hiato de recursos em TJLP no balanço do BNDES, ciclicamente ajustado, que se transformará em relevante obstáculo à retomada sustentada do investimento. Em razão do enrijecimento das restrições de crédito ao setor privado, tal medida limitará a tração sobre o 
investimento de eventual recuperação da confiança, gerando ônus sobre a intensidade da retomada econômica e, assim, sobre as próprias receitas tributárias da União e dos entes subnacionais.

\subsection{Custos líquido dos empréstimos do Tesouro Nacional ao BNDES}

Os empréstimos do Tesouro Nacional ao BNDES podem ser entendidos como parte de uma solução institucional desenhada para mitigar as falhas de mercado relevantes na intermediação da poupança macroeconômica, expressas no racionamento quase horizontal de crédito de longo prazo junto às fontes do mercado local, inibidoras do investimento privado.

Quando se ultrapassa a dimensão estritamente contábil, é provável, em especial nas condições de forte depressão no nível de atividade econômica e alta aversão ao risco das fontes privadas, que tal medida acabe por produzir efeito líquido negativo sobre o investimento, com efeitos dúbios sobre a trajetória das contas públicas no tempo.

A discussão sobre os efeitos fiscais de tais empréstimos usualmente omite a avaliação sobre os benefícios ao crescimento e à arrecadação derivados do enfrentamento do racionamento de crédito e da modulação do custo de capital, considerando a adicionalidade do investimento apoiado. Afinal, em um contexto institucional eivado de imperfeições e falhas de mercado na intermediação privada, parte relevante dos projetos seria abortada sem o apoio do BNDES.

Tende-se neste debate, ademais, a sobre-estimar os custos financeiros inscritos na relação bilateral entre o BNDES e o Tesouro. Em regra, os analistas desconsideram dimensões relevantes de tal relacionamento, além de omitirem os efeitos fiscais indiretos da ação do banco derivados da adicionalidade sobre o investimento executado, e, assim, sobre o crescimento, o nível de renda e as receitas tributárias.

A ampliação da carteira de crédito vinculada ao apoio ao investimento, contratada com margens positivas, amplia a rentabilidade do banco, o que gera resultado bruto da intermediação financeira que retorna ao Erário como pagamento de tributos, dividendos ou retenção de capital de um banco integralmente da União.

A título ilustrativo, o BNDES pagou mais de R\$ 100 bilhões, de 2009 a 2014, entre tributos e dividendos, em valores corridos pela Selic para data base de julho de $2015^{30}$. Estes ganhos, decorrentes do crescimento da carteira de ativos com margens positivas, são apropriados pelo Erário sobre a forma de pagamentos incrementais de dividendos e tributos vinculados ao resultado do banco, que, ceteris paribus, crescem em função da ampliação da carteira de créditos de elevada qualidade e do suporte ao crescimento das empresas brasileiras.

(30) http://www1.folha.uol.com.br/opiniao/2015/08/1673524-o-bndes-e-o-tesouro-nacional.shtml. 
A Tabela abaixo reproduz exercício efetuado por técnicos do BNDES ${ }^{31}$. Ele apresenta estimativas de custos diretos ao Erário em função do diferencial entre a Selic e a TJLP incidentes sobre o saldo projetado dos empréstimos ao longo do tempo. Tais custos diretos devem ser deduzidos dos ganhos incrementais decorrentes da margem de intermediação bruta positiva do BNDES nas operações apoiadas com os empréstimos do Tesouro - que viabilizam ampliação da carteira que gera resultado incremental do banco, que regressa ao Erário como tributos, dividendos ou retenção de capital de empresa de controle exclusivo.

Tabela 1

Custo Líquido dos Empréstimos do Tesouro ao BNDES

Valor Presente de Custos e Benefícios a Serem Incorridos ao Longo de 45 Anos

\begin{tabular}{|c|c|c|c|c|c|c|}
\hline & \multicolumn{2}{|c|}{ Cenário 1} & \multicolumn{2}{|c|}{ Cenário 2} & \multicolumn{2}{|c|}{ Cenário 3} \\
\hline & R\$ bilhões & $\%$ PIB a.a. & R\$ bilhões & $\%$ PIB a.a. & R\$ bilhões & $\%$ PIB a.a. \\
\hline Custo devido ao diferencial entre a Selic e a TJLP & 180,7 & $0,07 \%$ & 176,05 & $0,07 \%$ & 199,71 & $0,08 \%$ \\
\hline Margem do BNDES cobrada das empresas ${ }^{* *}$ & $-136,2$ & $-0,06 \%$ & $-140,04$ & $-0,06 \%$ & $-129,70$ & $-0,05 \%$ \\
\hline $\begin{array}{l}\text { Arrecadação sobre o Investimento Adicionado (sem } \\
\text { efeito multiplicador) }\end{array}$ & $-88,4$ & $-0,04 \%$ & $-90,90$ & $-0,04 \%$ & $-84,19$ & $-0,04 \%$ \\
\hline Custo Líquido sem equalização & $-43,9$ & $-0,02 \%$ & $-54,89$ & $-0,02 \%$ & $-14,18$ & $-0,01 \%$ \\
\hline
\end{tabular}

* Todos os dados, inclusive de PIB, estão a valor presente, de 30/06/2015.

** O resultado da margem do BNDES e da arrecadação entram com sinal negativo por reduzirem o custo líquido.

***Hipóteses, contas feitas refletindo condições de agosto de 2015:

Margem bruta da intermediação do BNDES, líquida de custos operacionais $=1,8 \%$ a.a.,

Adicionalidade do investimento em função do crédito apoiado $=23 \%$;

Prazo médio de retorno dos créditos do BNDES $=5$ anos;

TJLP cenário 1 e 3 = estabiliza em 7,5\%, TJLP cenário 2 = cai para $6 \%$;

Selic cenário 1: Cai do patamar de 14,5\% até $10 \%$ em dez. 2018 e se estabiliza neste patamar

Selic cenário 2: Cai do patamar de 14,5\% até $8 \%$ em dez. 2022 e se estabiliza neste patamar

Selic cenário 3: Cai do patamar de 14,5\% até 11,8\% em jan. 2020 e 10\% em jan. 22, e estabilizando neste patamar Fonte: "Custo Líquido dos Empréstimos do Tesouro ao BNDES", Nota APE a AF, BNDES, 08/2015.

Tais valores devem ser acrescidos dos benefícios líquidos indiretos estimados. Esses representam estimativas de tributos incidentes diretamente sobre o valor dos investimentos adicionados pela ação do BNDES. Baseou-se em estimativa da adicionalidade relativamente modesta, em que investimentos correspondentes a $23 \%$ do valor apoiado seriam abortados na ausência da atuação do banco.

(31) "Custo Líquido dos Empréstimos do Tesouro ao BNDES", Nota conjunta APE e AF, BNDES, agosto de 2015: http://www.bndes.gov.br/SiteBNDES/export/sites/default/bndes_pt/Galerias/Arquivos/empresa/download/Custo_Liquido_Empr estimos_Tesouro_BNDES.pdf. O exercício reflete a projeção do esquema de amortização das dívidas contratados, vigente antes da devolução antecipada dos R $\$ 100$ bilhões ao fim de 2016.

(32) O estudo em referência, realizado pelo setor de pesquisa do BNDES, baseou-se em estimativa de que para cada R\$ 100 desembolsados para apoio ao investimento, aproximadamente R \$ 23 não ocorreriam na ausência do Banco. A estimativa é conservadora. Segundo o mesmo estudo, estimativas mais recentes indicam uma adicionalidade de 37\%. Outros trabalhos, cobrindo período e usando métodos distintos, também chegam a valores superiores aos 23\%. Ver Thiago Rabelo Pereira, Adriano Simões e André Carvalhal / Rio de Janeiro, setembro de 2011. 
A estimativa do benefício indireto derivado do apoio do BNDES deixou de considerar o ganho tributário decorrente do efeito multiplicador desencadeado pelo investimento adicionado sobre a renda gerada, assim como deixou de capturar o valor associado ao excedente econômico gerado pelas externalidades oriundas dos projetos viabilizados. Ainda assim, em cenários plausíveis, são observados resultados com ganho fiscal esperado ao Erário ao longo do tempo (números negativos representam ganho líquido).

Tais estimativas indicam ser plausível a conjectura de que na ausência da ação do BNDES em escala sistemicamente relevante, viabilizada pelos empréstimos da União, a trajetória contrafactual da relação dívida líquida/PIB poderia ser mais elevada ao longo do tempo, uma vez incorporados os efeitos derivados da contribuição do BNDES ao investimento e ao crescimento de longo prazo.

O custo fiscal líquido dos empréstimos é fator condicionante da evolução do estoque da dívida líquida ao longo do tempo, enquanto a redução do potencial de crescimento de longo prazo, na ausência de ação corretiva do banco de fomento, afetaria negativamente a evolução do denominador da relação dívida/PIB.

O exercício sugere que o custo fiscal líquido do carregamento dos empréstimos do BNDES pode ser bastante baixo, nulo ou até mesmo positivo para o Erário, em condições plausíveis de adicionalidade do investimento apoiado. Ou seja, não parece ter fundamento a afirmação de que a manutenção do patamar atual de ação corretiva do orçamento do BNDES é insustentável do ponto de vista fiscal.

Vale esclarecer que eventual folga de recursos do BNDES, como a verificada em função da recessão, é neutra do ponto de vista do custo fiscal de carregamento dos empréstimos. Os recursos "ociosos" são aplicados em títulos públicos ou operações compromissadas, remuneradas pelo custo de financiamento do $\mathrm{TN}$ - usualmente a Selic, o que gera resultado extraordinário de tesouraria, que volta ao Erário pelos canais já referidos (tributos, dividendos ou retenção de capital).

Ao contrário do afirmado pelas autoridades no anúncio da intenção de devolução antecipada dos empréstimos, se os recursos estão "ociosos" no BNDES, eles não acarretam em custo fiscal de carregamento direto para a União, o que só ocorre quando são emprestados em apoio a projetos de investimento.

Importa, portanto, reter que é no momento em que os recursos são utilizados emprestados para apoiar projetos de investimento produtivo - que passam a incorrer custos de carregamento diretos. Entretanto, estes passam a ser mitigados tanto pelo efeito do crescimento da carteira de crédito do banco, contratada com margens positivas, quanto pelo efeito do investimento adicionado sobre a renda do setor privado, que compõe a base de extração das receitas tributárias.

Por fim, é usual no debate público a afirmação de que os desembolsos do BNDES no período 2008-2014 teriam crescido expressivamente sem que o esforço agregado de 
investimento tivesse sido ampliado. Tal afirmação carece de fundamentação empírica, como pode ser aferido pela simples avaliação visual do Gráfico 4 . O coeficiente de correlação entre a trajetória da formação bruta de capital e o valor dos desembolsos do banco em apoio ao investimento é da ordem de $95 \%$.

Gráfico 4

Desembolsos do BNDES para apoio ao investimento vs. FBCF

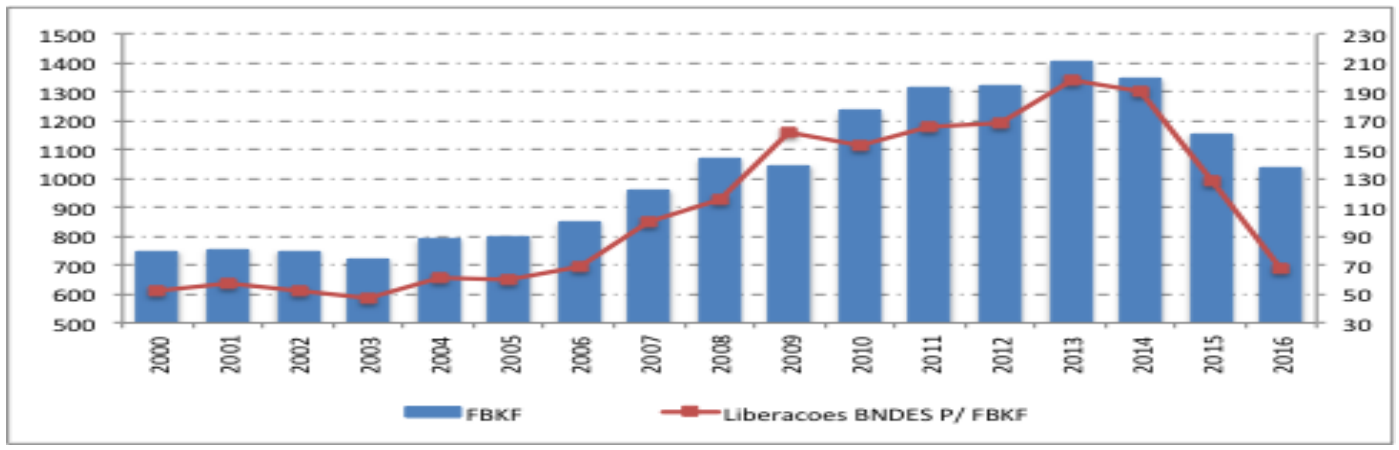

Fonte: BNDES ${ }^{33}$. Valores em R\$ bi de jun./2017. FBCF eixo da esquerda. Apoio BNDES, eixo da direita.

Esse quadro é reforçado pela constatação de que a taxa de investimento média da economia brasileira de 2000 a 2007 foi de $17 \%$ do PIB, tendo subido para $20 \%$ no período em que ocorreram os empréstimos do TN ao BNDES (2008-2014).

\subsection{Existem alternativas menos danosas de obtenção de mesmo resultado contábil sobre a estatística de dívida bruta?}

Mesmo desconsiderando os aspectos legais e institucionais relativos à vedação da devolução antecipada dos empréstimos pela LRF, anteriormente mencionados, e admitindo, por hipótese, ser desejável em alguma medida perseguir a redução da dívida bruta, sem variação correspondente da Dívida Líquida do Setor Público, existiriam ainda assim formas economicamente menos danosas de obter o efeito contábil desejado do que limitar a escala de ação do BNDES.

As operações de empréstimo do Tesouro Nacional ao BNDES correspondiam a quase $1 / 3$ da diferença em dezembro de 2016 (antes da primeira antecipação de $\mathrm{R} \$ 100$ bilhões) entre a Dívida Bruta do Governo Geral e a Dívida Líquida do Setor Público. O grosso de tal diferença corresponde ao estoque de reservas internacionais, com sua contrapartida na esterilização de liquidez, mediante contratação de operações compromissadas do BC com o mercado.

As reservas internacionais ao final de 2016 eram de US\$ 372,2 bilhões. Ao câmbio corrente da mesma data de $\mathrm{R} \$ 3,26$ por dólar, elas correspondiam a 19,4\% do PIB em haveres líquidos, denominados em moeda estrangeira, com elevada qualidade de crédito. A esse

(33) “O BNDES e o Investimento:2000 a 2016” (Puga; Gabrielli). 
patamar de taxa de câmbio seria possível gerar redução equivalente aos R 100 bilhões efetuados da estatística de dívida bruta com a venda de cerca de US\$ 30 bilhões das reservas internacionais.

Caso seja considerada a intensidade do ajuste observado em conta corrente no passado recente, ou quaisquer outros indicadores selecionados de vulnerabilidade externa, em quadro marcado por realinhamento cambial, é razoável afirmar que o custo implícito do carregamento das reservas elevou-se fortemente.

O benefício marginal associado ao carregamento das reservas equivale à taxa de juros livre de risco recebida em moeda forte - próxima de zero nas condições correntes - acrescida da desvalorização cambial esperada e do valor implícito atribuído à retenção de reservas, visto como uma espécie de seguro quanto aos riscos da volatilidade das condições de acesso ao financiamento externo.

O valor implícito desse "seguro" compõe o benefício marginal da retenção de reservas, devendo ser contraposto ao seu custo esperado de carregamento, que equivaleria ao "prêmio do seguro".

O valor do "seguro" deve ter caído fortemente no passado recente, tendo em vista a expressiva redução da vulnerabilidade externa decorrente da rápida e intensa redução do déficit em conta corrente processado na economia brasileira. A razão entre o estoque de reservas cambiais e o déficit em conta corrente indica elevação expressiva do colchão de segurança oferecido pelas reservas, ainda que fossem vendidas em quantia equivalente à redução da dívida bruta em R $\$ 100$ bilhões.

Tabela 2

Razão entre reservas internacionais e resultado em conta corrente

\begin{tabular}{|c|c|c|c|c|c|}
\hline Brasil - Balanço de Pagamento & 2013 & 2014 & 2015 & 2016 & 2017 \\
\hline Resultado em Conta Corrente - USD Bi & $-74,84$ & $-104,20$ & $-59,45$ & $-23,68$ & $-9,81$ \\
\hline Resultado em Conta Corrente - \% PIB & $-3,03 \%$ & $-4,24 \%$ & $-3,31 \%$ & $-1,32 \%$ & $-0,48 \%$ \\
\hline Reservas Internacionais - posição fim de ano / USD BI & 359 & 364 & 356 & 365 & 374 \\
\hline Razão entre Reservas e Resultado em Conta Corrente & 4,79 & 3,49 & 6,00 & 15,41 & 38,14 \\
\hline Razão entre Reservas e Resultado em Conta Corrente - venda liquidas de USD 30 bi & 4,39 & 3,20 & 5,49 & 14,15 & 35,08 \\
\hline
\end{tabular}

Fonte: Bacen.

O custo de carregamento das reservas subiu pela manutenção de alto diferencial entre os juros domésticos e os externos, conjugado a uma trajetória de realinhamento do câmbio nominal - com consequente redução da depreciação futura esperada. Tal efeito é observado ao mesmo tempo em que o benefício intangível de seu carregamento reduziu-se fortemente, em função da melhora nas contas externas, prova de que o regime de câmbio flexível funciona satisfatoriamente como fator de absorção de choques externos.

Considerando-se (i) os fatores acima citados que sugerem redução no nível desejável de carregamento de reservas, (ii) o crescimento esperado do efeito de adicionalidade do apoio 
do BNDES sobre o investimento em conjuntura marcada por ampla disponibilidade de recursos ociosos e de alta aversão ao risco das fontes privadas, (iii) que recursos eventualmente ociosos no caixa do banco não possuem custo fiscal efetivo ao Erário: é inescapável apontar que seria preferível otimizar o estoque de reservas com venda líquida de cerca de US\$ 30 bilhões dos aproximadamente US\$ 375 bilhões carregados atualmente, em vez de ter efetuado a antecipação dos $\mathrm{R} \$ 100$ bilhões.

Tal processo poderia ser coordenado ao manejo simétrico da posição de swaps cambiais do BC para evitar pressão sobre a trajetória do câmbio e a alteração da posição comprada líquida do setor público consolidado em moeda forte - fator de estabilização das contas fiscais a choques externos.

Foi preferível reduzir o poder de fogo do BNDES em suporte à retomada do investimento, especialmente em cenário contingente de restauração da confiança?

Outra alternativa poderia apontar na direção de se dissociar a discussão sobre a absorção dos custos fiscais diretos - decorrentes do diferencial entre a taxa aplicável ao funding do BNDES e o custo de captação soberano em mercado, incidente sobre o estoque dos empréstimos - da sensibilização direta da dívida bruta da União.

Pode-se conceber estratégia em que o BNDES financie a antecipação de parte das dívidas com o TN, restrita em volume ao funding das linhas de financiamento de operações indiretas voltadas às micro, pequenas e médias empresas, de menor prazo médio, através de emissões diretas de dívida junto a fontes de mercado, eventualmente com ajustes regulatórios para permitir maior profundidade de suas colocações diretas. Tal pré-pagamento poderia ser coordenado à contratação de compromisso de equalização do custo de captação do BNDES em mercado em relação à taxa aplicável (substituta da TJLP), em prazo igual ao do empréstimo original a ser liquidado. $\mathrm{O}$ Tesouro absorveria o custo fiscal-financeiro direto via equalização, mas poderia capturar a almejada redução do principal na estatística de dívida bruta, sem estrangular financeiramente a retomada do investimento produtivo, gerando uma fonte "sintética" com custo potencialmente favorecido (TLP, com redutor).

Tal arranjo evitaria que a solução institucional criada para mitigar o problema econômico real do excessivo racionamento de crédito de longo prazo junto às fontes privadas fosse mediado pela sensibilização direta da dívida bruta da União, mas poderia gerar, sob certos limites, efeito financeiro equivalente ao dos empréstimos, sob a ótica da preservação da capacidade do BNDES atuar como fator de suporte à recuperação do investimento e atuar na correção de falhas de mercado relevantes na intermediação financeira privada ${ }^{34}$.

(34) Outra opção que poderia ser discutida em maior profundidade consiste na proposta levantada pelo então ministro Nelson Barbosa sobre eventual substituição das operações compromissadas por depósitos remunerados junto à autoridade monetária, visando drenar liquidez do sistema bancário com instrumento que não é contabilizado na dívida bruta, de forma a segregar claramente da estatística da dívida o componente vinculado a operacionalidade da política monetária. 


\section{Considerações finais}

O BNDES é um banco de desenvolvimento com um tamanho compatível aos dos principais BDs do mundo. No entanto, a falha macroeconômica estrutural que faz a economia brasileira manter taxas de juro persistentemente elevadas faz com que sua atuação pareça singular no mundo, sugerindo uma disfuncionalidade.

De fato, a provisão de melhores condições ao financiamento do investimento produtivo - mitigando os efeitos deletérios do juro alto sobre atividades dinâmicas, como ampliação de capacidade, modernização tecnológica, inovação e exportação - faz do BNDES algo singular, tendo uma participação sem igual no crédito total da economia. Mas a disfuncionalidade não está no banco de fomento e, sim, no juro dito de mercado.

O debate econômico em um contexto de intenso conflito distributivo e político fez com as iniciativas para lidar com os problemas do juro alto fossem voltadas para enfraquecer o BNDES e seus instrumentos de atuação, como se o remédio, ainda que voltado para mitigar os sintomas, fosse a causa da disfunção.

Este artigo tentou mostrar que as duas iniciativas do governo federal - a criação da TLP em substituição da TJLP, associada a um título público de cinco anos, e a devolução antecipada de recursos emprestados pelo Tesouro Nacional ao BNDES de 2008 a 2014- são inadequadas para enfrentar as causas efetivas do juro persistentemente elevado e ainda põe em risco os instrumentos criados para mitigar parte de seus efeitos indesejados e estimular o desenvolvimento.

A TJLP era fixada pela equipe econômica, que podia calibrar a prioridade que desejava dar ao investimento ponderando o custo fiscal gerado pela sua diferença em relação à Selic, igualmente definida pelo governo. A TLP é uma taxa que pode ser procíclica, que traz de volta a indexação ao IPCA, volátil e que deixa o BNDES sem uma vantagem de custo estrutural (menor taxa de captação ou imunidade tributária) que os BDs, mesmo em seus modelos mais exíguos, possuem para conseguir viabilizar projetos que geram grandes externalidades (benefícios sociais não capturados no preço).

A avaliação sobre a escala e o perfil desejável da ação do BNDES deve certamente incluir a dimensão fiscal, sempre lembrando que os seus efeitos líquidos sobre as contas públicas dependerão da conjugação do tamanho potencial de seu balanço e de suas liberações, do nível da TJLP/TLP e da Selic, da política de precificação do apoio financeiro das linhas de crédito oferecidas pelo banco às distintas atividades, e da aferição dos benefícios fiscais decorrentes da adicionalidade líquida ao crescimento econômico, derivada de sua ação corretiva sobre o volume e o perfil do investimento agregado, assim como do modelo de funding adotado.

A antecipação pelo BNDES dos empréstimos tomados com o Tesouro Nacional se prende a uma estratégia de viabilizar uma melhora das estatísticas fiscais da dívida bruta, sem uma contrapartida econômica real na melhora da situação patrimonial do setor público. $\mathrm{O}$ objetivo efetivo parece ser o de reduzir o BNDES. 
O resgate antecipado dos recursos do Tesouro emprestados ao BNDES, além de gerar dúvidas sobre sua legalidade (LRF), negligencia o papel do banco na mitigação do racionamento de crédito de longo prazo, desconsidera os benefícios diretos e indiretos dos investimentos financiados pelos empréstimos sobre a situação patrimonial do setor público, atribui erroneamente custos fiscais à "ociosidade" momentânea de recursos no banco enquanto estes estão aplicados em ativos com rentabilidade igual ao dos passivos do setor público e silencia sobre alternativas mais eficientes de redução da dívida bruta.

A convergência estrutural do custo de captação do Tesouro com o custo aplicável ao funding institucional do BNDES é altamente desejável, já que significaria fazer o país ter juros compatíveis com os praticados internacionalmente e com os retornos e os prazos de maturação de grande parte dos investimentos produtivos.

Essa convergência é fundamental para que a indústria financeira, ao deixar de contar com o porto seguro de títulos públicos rentáveis e líquidos, tenha apetite por tomar riscos em operações de maior duration.

Inverter o argumento, fazendo crer que a ausência do BNDES propiciará espontaneamente o surgimento de mercados de títulos privados profundos e maduros desafia a experiência histórica e o bom senso. Corre-se o risco de destruir o BNDES e ficar "esperando Godot", aguardando, como que por encanto, o necessário e desejável florescimento das fontes do mercado de crédito e capitais.

Mais razoável é ajustar o papel do BNDES, com foco progressivo nas atividades intensivas em externalidades. Na medida em que a economia se recupere, a Selic caia e as fontes privadas se mostrarem aptas a assumir maiores protagonismos no financiamento ao investimento em condições aceitáveis de custo, prazo e volume, sem que o "desenvolvimento" das fontes de mercado privado gerem o deslocamento (crowding out) dos investimentos produtivos, o BNDES poderá ter um papel diferente, ainda que não necessariamente menos relevante.

Nesse sentido, uma opção é manter a TLP, mas conferir ao CMN a prerrogativa de aplicar redutores, horizontais ou focados em atividades especificas, caso julgue adequado em cada conjuntura. Conforme as exigências de cada contexto, seria possível:

i) filtrar surtos de volatilidade excessiva da NTN-B de cinco anos;

ii) conceder um incentivo horizontal ao investimento, em especial em momentos de grande capacidade ociosa e desemprego involuntário;

iii) focar em setores específicos e atividades intensivas em externalidades para proporcionar uma redução do custo do crédito, de maneira a alinhar o retorno privado ao retorno social dos projetos.

iv) preservar graus de liberdade para execução de políticas de crédito em articulação a outras políticas industriais e de desenvolvimento. 


\section{Referências bibliográficas}

ALÉM, Ana Cláudia; Madeira, Rodrigo Ferreira; Martini, Ricardo Agostini. Sistemas nacionais de fomento: experiências comparadas. In: PRÊMIO ABDE-BID: COLETÂNEA DE TRABALHOS. Rio de Janeiro, Associação Brasileira de Desenvolvimento, 2015. p. 69-104. Disponível em: https://web.bndes.gov.br/bib/jspui/handle/1408/10654.

BERNANKE, Ben. The Federal Reserve and the Financial Crises - Lectures by Ben Bernanke. Princeton University Press, 2013.

BOLLE, Mônica Baumgarten de. do public development banks hurt growth? evidence from Brazil. Peterson Institute for International Economics - Policy Brief, Sept. 2015. Disponível em: https://piie.com/publications/pb/pb15-16.pdf

BOLLE, Mônica Baumgarten de. O BNDES eleva a produtividade? Folha de S. Paulo, 3 set. 2015. Disponível em: http://www1.folha.uol.com.br/colunas/monica-debolle/2015/09/1677109-o-bndes-eleva-a-produtividade.shtml.

CUSTO Líquido dos Empréstimos do Tesouro ao BNDES. Nota conjunta APE a AF, BNDES, ago. 2015. Disponível em: https://www.bndes.gov.br/SiteBNDES/export/sites/default/ bndes_pt/Galerias/Arquivos/empresa/download/Custo_Liquido_Emprestimos_Tesouro_BND ES.pdf.

FERRAZ, João Carlos; MARQUES, Felipe Silveira; LEAL, Cláudio Figueiredo; MITERHOF, Marcelo Trindade. Financing development: the case of BNDES. In: STIGLITZ, J.; JUSTIN, Lin (Ed.). The industrial policy revolution I: the role of government beyond ideology. Pallgrave Macmillan, 2013.

GRIFFITH-JONES, S. Development banks and their key roles: supporting investment, structural transformation and sustainable development. Bread for the World, 2016. (Discussion Paper, n. 59). Disponível: http://www.stephanygj.net/papers/Development banks_and_their_key_roles_2016.pdf.

GRIFFITH-JONES, S.; COZZI, G. The roles of development banks; how they can promote investment, in Europe and globally. In: NOMAN, A.; STIGLITZ, J. (Ed.). Efficiency, finance, and varieties of industrial policy: guiding resources, learning, and technology for sustained growth. Columbia University Press, 2016. Dispinível em: http://www.stephanygj.net/papers/The_roles_of_development_banks_how_they_can_promot e investment in Europe and globally 2016.pdf.

KAWALL, Carlos. Dinâmica da dívida bruta. Apresentação Banco Safra, 2015. Disponível em: http://iepecdg.com.br/wp-content/uploads/2016/03/Carlos Estudo_Divida-1.ppt.

LAZZARINI, Sergio et al. What do state-owned development banks do? Evidence from BNDES, 2002- 2009. World Development, n. 66, p. 237-256, 2015. 
LOPES, Francisco. The transmission mechanism of monetary policy in a stabilizing economy: notes on the case of Brazil. Basle: BIS, Jan. 1998. (Policy Papers, n. 3). Disponível em: https://www.bis.org/publ/plcy03.pdf.

MACHADO, Luciano; GRIMALDI, Daniel; ALBUQUERQUE, Breno; SANTOS, Leonardo. Additionality of countercyclical credit: evaluating the impact of BNDES' PSI on the investment of industrial firms. nov. 2014. (Working Paper). Disponível em: https://www.bndes.gov.br/SiteBNDES/export/sites/default/bndes_pt/Galerias/Arquivos/conhe cimento/efetividade/additionality of countercyclical credit.pdf.

MAZZUCATTO, Mariana. The entrepreneurial state - debunking public vs. private sector myths. Public Affairs, New York, 2015.

MEHRLING, Perry. The New Lombard Street: how the Fed became the dealer of last resort. Princeton University Press, 2010.

MITERHOF, Marcelo Trindade; FERRAZ, João Carlos; MARQUES, Felipe Silveira. BNDES: preenchendo lacunas, corrigindo falhas e induzindo externalidades. In: BARBOSA. Nelson et al. (Org.). Indústria e desenvolvimento produtivo no Brasil. Rio de Janeiro: Elsevier; FGV, 2015. p. 467-483.

MODENESI, André de Melo; Araújo, Eliane Cristina de. Price stability under inflation targeting in Brazil: empirical analysis of the monetary policy transmission mechanism based on var model, 2000-2008". Investigación Económica, v. LXXII, n. 283, p. 95-127, Jan./Mar. 2013.

PEREIRA, Thiago Rabelo; SIMÕES, Adriano; CARVALHAL, André. Mensurando o resultado fiscal das operações de empréstimo do Tesouro ao BNDES: custo ou ganho líquido esperado para a União? Rio de Janeiro: Ipea, set. 2011. (Texto para Discussão, n. 1665). Disponível em: http://repositorio.ipea.gov.br/bitstream/11058/1184/1/td_1665.pdf.

RELATÓRIO trimestral de prestação de contas ao Congresso Nacional sobre o uso dos recursos Emprestados pelo Tesouro ao BNDES. Disponível em: https://www.bndes.gov.br/SiteBNDES/export/sites/default/bndes_pt/Galerias/Arquivos/empr esa/download/Relatorio Recursos Financeiros 4trimestre2015.pdf.

RELATÓRIO de efetividade 2007-2014: a Contribuição do BNDES para o Desenvolvimento Nacional. Disponível em: https://www.bndes.gov.br/SiteBNDES/export/sites/default/ bndes_pt/, http://www.valor.com.br/financas/4527647/para-stiglitz-criticas-atuacao-dobndes-dificultam-retomada.

SIFFERT Filho, Nelson Fontes; PUGA, Fernando Pimentel. A infraestrutura de transporte nos Estados Unidos: em busca do funding. Rio de Janeiro: BNDES, dez. 2016. (Texto para Discussão, n. 113). Disponível em: https://web.bndes.gov.br/bib/jspui/bitstream/ 1408/10416/1/TD_113_dez.\%202016_P.pdf.

STIGLITZ, Joseph E.; WEISS, Andrew. Credit rationing in markets with imperfect information. The American Economic Review, v. 71, n. 3, p. 393-410, Jun. 1981. 